\title{
CORONAVIRUS
}

Cite as: Y. Zuo et al., Sci. Transl. Med.

10.1126/scitranslmed.abd3876 (2020).

\section{Prothrombotic autoantibodies in serum from patients hospitalized with COVID-19}

\begin{abstract}
Yu Zuo', Shanea K. Estes' ${ }^{1}$, Ramadan A. Ali' ${ }^{1}$, Alex A. Gandhi', Srilakshmi Yalavarthi', Hui Shi',2, Gautam Sule', Kelsey Gockman', Jacqueline A. Madison ${ }^{1}$, Melanie Zuo ${ }^{3}$, Vinita Yadav ${ }^{4}$, Jintao Wang ${ }^{5}$, Wrenn Woodard ${ }^{6}$, Sean P. Lezak ${ }^{6}$, Njira L. Lugogo ${ }^{7}$, Stephanie A. Smith ${ }^{8}$, James H. Morrissey ${ }^{8}$, Yogendra Kanthi ${ }^{4,5 *}$, and Jason S. Knight $^{1 *}$

'Division of Rheumatology, Department of Internal Medicine, University of Michigan, Ann Arbor, Michigan 48109, USA. 'Division of Rheumatology, Ruijin Hospital, Shanghai Jiao Tong University School of Medicine, Shanghai, China ${ }^{3}$ Division of Geriatric and Palliative Medicine, Department of Internal Medicine, University of Michigan, Ann Arbor, Michigan 48109, USA. ${ }^{4}$ Division of Cardiovascular Medicine, Department of Internal Medicine, University of Michigan, Ann Arbor, Michigan 48109, USA. ${ }^{5}$ Division of Intramural Research National Heart, Lung and Blood Institute Bethesda, Maryland 20892, USA. ${ }^{6}$ Michigan Clinical Research Unit, University of Michigan, Ann Arbor, Michigan 48109, USA, ${ }^{7}$ Division of Pulmonary and Critical Care Medicine, Department of Internal Medicine, University of Michigan, Ann Arbor, Michigan 48109, USA. ${ }^{8}$ Department of Biological Chemistry, University of Michigan, Ann Arbor, Michigan 48109, USA.

¥Yogendra Kanthi and Jason S. Knight are co-corresponding authors. Email: yogen.kanthi@nih.gov, jsknight@umich.edu
\end{abstract}

Patients with COVID-19 are at high risk for thrombotic arterial and venous occlusions. Lung histopathology often reveals fibrin-based occlusions in the small blood vessels of patients who succumb to the disease. Antiphospholipid syndrome is an acquired and potentially life-threatening thrombophilia in which patients develop pathogenic autoantibodies targeting phospholipids and phospholipid-binding proteins (aPL antibodies). Case series have recently detected aPL antibodies in patients with COVID-19. Here, we measured eight types of aPL antibodies in serum samples from 172 patients hospitalized with COVID-19. These aPL antibodies included anticardiolipin IgG, IgM and IgA; anti- $\beta 2$ glycoprotein I IgG, IgM, and IgA; and anti-phosphatidylserine/ prothrombin (aPS/PT) IgG and IgM. We detected aPS/PT IgG in $24 \%$ of serum samples, anticardiolipin IgM in $23 \%$ of samples, and aPS/PT IgM in $18 \%$ of samples. Antiphospholipid autoantibodies were present in $52 \%$ of serum samples using the manufacturer's threshold and in $30 \%$ using a more stringent cutoff ( $\geq 40$ ELISA-specific units). Higher titers of aPL antibodies were associated with neutrophil hyperactivity including the release of neutrophil extracellular traps (NETs), higher platelet counts, more severe respiratory disease, and lower clinical estimated glomerular filtration rate. Similar to IgG from patients with antiphospholipid syndrome, IgG fractions isolated from COVID-19 patients promoted NET release from neutrophils isolated from healthy individuals. Furthermore, injection of IgG purified from COVID-19 patient serum into mice accelerated venous thrombosis in two mouse models. These findings suggest that half of patients hospitalized with COVID-19 become at least transiently positive for aPL antibodies and that these autoantibodies are potentially pathogenic.

\section{INTRODUCTION}

Abnormal coagulation characteristics correlate with COVID-19 severity $(1,2)$. The presence of high D-dimer concentrations in plasma is an independent risk factor for death (1, 3-5). Early descriptions of COVID-19 coagulopathy identified this disorder as disseminated intravascular coagulation. However, most patients maintain normal concentrations of coagulation factors, fibrinogen, and platelets suggesting that COVID-19 induces a unique prothrombotic state that is distinct from traditional descriptions of sepsis-induced coagulopathy $(6,7)$. There are now increasing reports of venous thromboembolism in patients with COVID-19 $(8,9)$. This observation is despite concerns regarding under-diagnosis given baseline elevations in the biomarker D-dimer, as well as pragmatic challenges in obtaining diagnostic imaging while patients are in isolation. Arterial thrombosis including strokes and myocardial infarctions have also been described $(9,10)$. Histopathology of lung specimens from patients with severe disease shows not only characteristic findings of ARDS, but also evidence of fibrin-based occlusion of small blood vessels (11-13). There are several, possibly synergistic mechanisms by which SARS-CoV-2 infection may result in macrovascular and microvascular thrombosis (14). These include a cytokine storm that activates leukocytes, endothelium, and platelets; hypoxic vaso-occlusion; and direct activation of immune and vascular cells by virus infection. Furthermore, many patients hospitalized with COVID-19 exhibit neutrophil extracellular traps (NETs) in their blood (15, 
16) and these inflammatory cell remnants may also contribute to the prothrombotic milieu (17-20).

Antiphospholipid syndrome is an acquired thrombophilia, affecting at least 1 in 2000 individuals (21). Patients form durable autoantibodies to phospholipids and phospholipid-binding proteins (aPL antibodies), such as prothrombin and beta-2-glycoprotein I ( $\beta_{2}$ GPI). These autoantibodies engage cell surfaces, where they activate endothelial cells, platelets, and neutrophils $(22,23)$, thereby tipping the bloodendothelium interface toward thrombosis. A key feature of antiphospholipid syndrome is its ability to promote thrombosis in vascular beds of all sizes, including both arterial and venous circuits. The catastrophic variant of antiphospholipid syndrome is frequently fatal, and bears some similarities to the diffuse coagulopathy seen in patients with COVID-19 (24). Classification criteria for antiphospholipid syndrome (last updated in 2006) seek persistently positive testing for anticardiolipin autoantibodies (aCL antibodies) or anti- $\beta_{2}$ GPI autoantibodies ( $\mathrm{a} \beta_{2} \mathrm{GPI}$ antibodies) (25). The lupus anticoagulant test (a functional assay that screens for aPL antibodies based on their paradoxical ability to prolong in vitro clotting assays) is also included in the criteria and detects a variety of species of aPL antibodies including anti-phosphatidylserine/prothrombin autoantibodies (aPS/PT antibodies) (26).

Reports of aPL antibodies in COVID-19 and their possible relationship to thrombosis have begun to emerge in case reports and case series (27-32). Whereas viral infections are well-known triggers of transient aPL antibody production (33-36), the extent to which these short-lived autoantibodies are pathogenic has not been well defined. Here, we aimed to test for several types of aPL antibodies in serum samples from a cohort of 172 patients hospitalized with COVID-19. We also asked whether purified IgG fractions from these patients had prothrombotic properties in vitro and in two mouse models of thrombosis.

\section{RESULTS}

\section{Prevalence of aPL antibodies in serum from hospitalized COVID-19 patients}

Serum samples from 172 patients hospitalized with COVID-19 (table S1) were evaluated for eight different types of aPL antibodies. Of the 172 patients, $19 \%$ died and $8 \%$ remained in the hospital at the time of this analysis. Eightynine patients tested positive for at least one type of aPL antibody based on the manufacturer's cut-off, representing $52 \%$ of the entire cohort (Table 1). The lupus anticoagulant test, a functional assay that relies on altered coagulation times in plasma to detect antiphospholipid antibody activity, was not performed here given lack of access to fresh plasma samples. Among the various aPL antibodies tested, aPS/PT IgG had the highest prevalence (24\%), followed by aCL IgM (23\%) and
aPS/PT IgM (18\%) (Table 1). Forty-one patients (24\%) were positive for more than one type of aPL antibody and 13 (8\%) were positive for more than two types of aPL antibody. Fiftytwo patients $(30 \%)$ had at least one moderate- to high-titer aPL antibody (Table 1). Thirty-six patients had serum samples taken at multiple time points available for aPL antibody testing, which enabled longitudinal analysis (fig. S1). In Table 1, the highest available aPL antibody serum titer was used to classify positivity for each of these 36 patients . Seropositivity was also assessed using only the first available serum sample, with similar rates of positivity as presented in Table 1 (Table S2). To further elucidate the antigen specificity of autoantibodies in serum samples positive for aPS/PT antibodies, we measured anti-phosphatidylserine autoantibodies (aPS antibodies) in these serum samples. Neither aPS IgG nor aPS IgM correlated with aPS/PT antibody serum titers suggesting that aPS/PT antibodies in COVID-19 patient serum primarily recognized prothrombin (fig. S2). In summary, serum samples from $52 \%$ of patients hospitalized for COVID-19 were positive for aPL antibodies, with approximately two-thirds of those being detected at moderate-to-high titers. The majority of positive serum samples were associated with three types of autoantibodies: aPS/PT IgG, aCL IgM, and aPS/PT IgM.

\section{Clinical correlates of aPL antibodies}

We next asked whether the presence of aPL antibodies was associated with various clinical characteristics. Specifically, we assessed potential correlations of aPL antibodies with the ratio of oxygen saturation to fraction of inspired oxygen $\left(\mathrm{SpO}_{2} / \mathrm{FiO}_{2}\right.$, i.e., oxygenation efficiency), C-reactive protein in serum, D-dimer concentrations in plasma, platelet counts, absolute neutrophil counts, calprotectin in serum (a marker of neutrophil activation), and myeloperoxidase (MPO)-DNA complexes in serum (markers of neutrophil extracellular traps, NETs) (Table 2). Titers of aCL IgM correlated with all of these clinical and laboratory variables (Table 2 ). Neutrophil activation as indicated by calprotectin in serum was most consistently associated with the presence of aPL antibodies (Table 2). We also assessed a previously devised tool called the aPL score, which integrates and prioritizes data from the various aPL antibody types tested (37). The aPL score demonstrated a positive correlation with platelet count ( $\mathrm{p}=0.025)$, neutrophil activation $(\mathrm{p}=0.0007)$, and the presence of NETs $(\mathrm{p}=0.02)$ (Table 2).

We then examined clinical variables as they related to positive aPL antibody thresholds for each ELISA test. A positive test for any aPL antibody was associated with higher calprotectin in serum $(\mathrm{p}=0.009)$ and lower clinical estimated glomerular filtration rate (eGFR, $\mathrm{p}=0.03$ ) (Fig. 1A, B). These associations were also observed when comparing patient serum samples that were positive for aPS/PT antibodies to serum samples from the remainder of the cohort (calprotectin $\mathrm{p}=0.0008$; eGFR $\mathrm{p}=0.008$ ) (Fig. $1 \mathrm{C}, \mathrm{D}$ ) or serum samples 
without aPL antibodies (calprotectin $\mathrm{p}=0.001$; eGFR $\mathrm{p}=0.01$ ) (fig. S3). Nadir eGFR was lower in patients with a history of renal disease compared to those without $(\mathrm{p}=0.01)$ (fig. S4). Oxygenation efficiency tended to be impaired in patients with serum samples positive for aPL or aPS/PT antibodies compared to those whose serum samples lacked these antibodies, although group comparisons did not reach statistical significance (fig. S5). Similarly, peak troponin in serum and peak Ddimer in plasma tended to be higher in patients with a positive test for any aPL antibody or anti-PS/PT antibody, respectively (fig. S6). Given that obesity can affect the D-dimer concentration in plasma, we compared D-dimer plasma concentrations in COVID-19 patients with or without obesity, but did not find a difference (fig. S7). Thus, the presence of aPL antibodies in serum samples from patients with COVID-19 correlated with various clinical characteristics, especially neutrophil activation and impaired renal function.

\section{IgG isolated from COVID-19 patient serum triggers re- lease of NETs}

Work by our group and others has revealed that one prothrombotic function of aPL antibodies in patients with antiphospholipid syndrome is to trigger release of NETs (23, 38 ). Given that we recently detected elevated NETs in serum from patients with COVID-19 (15), we reasoned that IgG fractions purified from serum of patients with COVID-19 might be able to trigger NET release. We selected two COVID-19 patients with high serum a $\beta_{2}$ GPI IgG, two COVID-19 patients with high serum aPS/PT IgG, and two COVID-19 patients who lacked serum aPL antibodies. From these patients, we purified total IgG fractions and tested them alongside IgG pooled from two patients with active catastrophic antiphospholipid syndrome as well as a separate IgG pool from five patients with antiphospholipid syndrome who tested positive for aCL antibodies, a $\beta_{2}$ GPI antibodies, and lupus anticoagulant. The purity of isolated COVID-19 patient IgG was verified by SDSPAGE (fig. S8). To quantify NET release in vitro, we measured MPO activity released into the supernatant after digestion of NET DNA with micrococcal nuclease. The release of NETs from neutrophils isolated from healthy individuals doubled (compared with unstimulated neutrophils) when neutrophils were cultured with COVID-19 patient IgG samples positive for aPL antibodies (Fig. 2A, data file S1). This was similar to the degree of NET release induced in neutrophils by IgG samples from patients with antiphospholipid syndrome $(\mathrm{p}<0.0001)$ or catastrophic antiphospholipid syndrome $(\mathrm{p}=0.0001)$. Representative images of NET release induced by COVID-19 patient IgG are shown in Fig. 2B. We have previously shown that dipyridamole-an antithrombotic medication-can attenuate aPL antibody-mediated prothrombotic NET release by surface adenosine $A_{2 \mathrm{~A}}$ receptor agonism (39). Here, we found that dipyridamole also suppressed COVID-19 patient IgG-mediated NET release from neutrophils in vitro (fig. S9). IgG fractions purified from COVID-19 patient serum positive for aPL antibodies promoted NET release similar to IgG isolated from individuals with established antiphospholipid syndrome.

\section{IgG isolated from aPL antibody-positive patient serum potentiates thrombosis in mice}

We next sought to determine whether IgG fractions from COVID-19 patient serum could accelerate thrombosis. When tested in an in vitro cell-free thrombin generation assay, IgG fractions purified from COVID-19 patient serum did not have demonstrable clot-accelerating activity (fig. S10). Nevertheless, we speculated that a prothrombotic phenotype might still be observed in the cell-enriched vascular environment of mice. We have previously reported that IgG isolated from serum of patients with either triple-positive antiphospholipid syndrome or catastrophic antiphospholipid syndrome accelerates large-vein thrombosis in various mouse models of inferior vena cava thrombosis $(38-40)$. Here, we asked whether COVID-19 patient serum IgG might behave similarly to enhance thrombosis in these mouse models. We first used a mouse model in which a copper wire was placed inside the inferior vena cava in order to activate the endothelium by electrolysis-mediated free radical generation (Fig. 3A). In this model, IgG isolated from COVID-19 patients with a high serum titer of aPS/PT IgG increased thrombus extension (Fig. 3B) and overall accretion (Fig. 3C,D; data file S2) 24 hours after IgG intravenous injection. The high aPS/PT serum titer samples also increased NET remnants in mouse serum $(\mathrm{p}=0.0004)$, similar to IgG from patients with catastrophic antiphospholipid syndrome ( $\mathrm{p}=0.0014)$ (Fig. 3E; data file $\mathrm{S} 3$ ), and demonstrated a tendency toward higher expression of citrullinated histone H3 (a biochemical marker of NETs) in mouse thrombi by Western blotting (fig. S11). To confirm these findings, we turned our attention to an independent mouse model in which the inferior vena cava was narrowed just distal to the renal vein by a fixed suture placed over a spacer that was subsequently removed (Fig. 3F); thrombus size was measured 24 hours after IgG intravenous injection. In this "stenosis" mouse model of thrombosis, IgG from COVID-19 patients with a high aPS/PT serum titer also increased thrombus extension ( $\mathrm{p}=0.01$ ) (Fig. 3G), thrombus accretion ( $\mathrm{p}=0.003$ ) (Fig. $3 \mathrm{H}$, I; data file $\mathrm{S} 4$ ), and circulating NET remnants $(p=0.008)$ (Fig. 3J; data file S3) 24 hours after IgG intravenous injection. Taken together, these data indicate that IgG fractions from some patients with acute COVID19 were able to accelerate thrombosis in vivo.

\section{DISCUSSION}

Antiphospholipid autoantibodies (aPL antibodies) are a heterogeneous group of antibodies that underlie the pathogenesis of antiphospholipid syndrome via their interactions with phospholipid-binding plasma proteins such as $\beta_{2} \mathrm{GPI}$, 
prothrombin, thrombomodulin, plasminogen, antithrombin III, protein C, protein S, annexin II, annexin V, and likely others $(22,41-46)$. The association between various infections and the induction of aPL antibodies has long been recognized (47-52). For example, one study of 100 cases reported in Medline from 1983 to 2003 found the most commonly reported aPL antibody-associated infections to be skin infections (18\%), pneumonia (14\%), and urinary tract infections (10\%); common pathogens included human immunodeficiency virus (17\%), varicella-zoster virus (15\%), and hepatitis $\mathrm{C}$ virus (13\%) (50). Regarding specific aPL antibodies, aCL IgG and IgM (typically lacking anti- $\beta_{2}$ GPI antibody activity) have been most commonly reported $(48,52-57)$. The majority of these virus-associated aPL antibodies are thought to be transient $(35,54,58)$. Although the clinical implications of transient virus-associated aPL antibodies remain to be fully defined, a recent review of 163 published cases of virus-associated aPL antibodies found thrombotic events in 116 cases (35). Even acknowledging the likelihood of sampling and publication bias, these data (along with the data presented here for individuals with severe COVID-19) suggest that some transient aPL antibodies may still have prothrombotic potential. Whether similar antibodies would be detected in patients with less symptomatic COVID-19 presentation-some of whom do experience thrombotic events-awaits further study.

The most severe presentation of antiphospholipid syndrome is its catastrophic variant, which fortunately impacts only a minority of patients with antiphospholipid syndrome, typically at times of stress such as infection, surgery, or withdrawal of anticoagulants (59). Catastrophic antiphospholipid syndrome involves derangements of both inflammatory and thrombotic pathways and impacts multiple organs in the body simultaneously (59). In the largest series of patients with catastrophic antiphospholipid syndrome assembled, the most commonly affected organs were kidneys (73\%), lungs (60\%), brain (56\%), heart (50\%), and skin (47\%) (60). Whereas multi-organ failure certainly complicates severe cases of COVID-19, the lungs are typically the most severely affected organ. We speculate that local immune stimulation due to viral infection (including potentially the infection of endothelial cells) could synergize with circulating aPL antibodies and thereby lead to a particularly severe thrombo-inflammatory insult to the lungs of COVID-19 patients.

Many studies from the general thrombosis literature have revealed that activated neutrophils, and in particular NET formation, contribute to the propagation of thrombi affecting arterial, venous, and microscopic vascular beds $(61,62)$. NETs have also been recently implicated in the pathogenesis of antiphospholipid syndrome. Our group has reported that serum samples from patients with antiphospholipid syndrome, as well as purified aPL antibodies, trigger neutrophils to release
NETs (23). The potential in vivo relevance of this observation has been confirmed in mouse models of aPL antibody-mediated large-vein thrombosis in which either depletion of neutrophils or digestion of NETs was protective (38). Neutrophils from patients with antiphospholipid syndrome also appear to have increased adhesive potential, which is dependent upon the activated form of integrin Mac-1. This pro-adhesive phenotype amplifies neutrophil-endothelium interactions, potentiates NET formation, and potentially lowers the threshold for thrombosis (63). Therapies that target NET formation have the potential to treat thrombotic diseases. For example, selective agonism of the adenosine $\mathrm{A}_{2 \mathrm{~A}}$ receptor suppresses aPL antibody-mediated NETosis in a protein kinase A-dependent fashion (39). $\mathrm{A}_{2 \mathrm{~A}}$ receptor agonism also reduces thrombosis in the inferior vena cava of both control mice and mice treated with aPL antibodies. Dipyridamole, which is known to potentiate adenosine receptor signaling by increasing extracellular concentrations of adenosine and interfering with the breakdown of cAMP, also suppresses aPL antibodymediated NETosis and mitigates venous thrombosis in mice (64). Interestingly, a small study from China showed that dipyridamole suppressed D-dimer elevation and improved platelet counts in patients with COVID-19 (65). Whereas we have demonstrated here that dipyridamole mitigated NET release mediated by IgG from COVID-19 patients, prospective randomized clinical trials (NCT04391179) are needed to evaluate clinical outcomes among COVID-19 patients treated with dipyridamole (64).

aPL antibodies are defined based on their inclusion in the updated Sapporo classification criteria: namely, aCL IgG and IgM, a $\beta_{2}$ GPI IgG and IgM, and lupus anticoagulant (25). Of these, lupus anticoagulant is generally accepted as the best indicator of a high-risk aPL antibody profile (66-71). There are certainly reports of patients with seronegative antiphospholipid syndrome, who have classic features of this disease but have tested negative for traditional aPL antibodies (72). Some non-criteria aPL antibodies discovered in the past 20 years have shown promising clinical utility in identifying antiphospholipid syndrome. Among those are aPS/PT IgG and IgM, as well as the IgA isotypes of aCL and $a \beta_{2}$ GPI antibodies. Retrospective studies have suggested that $\mathrm{a}{ }_{2}{ }_{2}$ GPI IgA is associated with thrombosis in lupus patients [odds ratio (OR) 2.8, 95\% CI 1.3-6.2] (73). A recent review of 10 retrospective studies (1775 patients with lupus or primary antiphospholipid syndrome and 628 healthy controls) detected a strong association between aPS/PT antibodies and thrombotic events (OR 5.11; 95\% CI 4.2-6.3) (74). Furthermore, serological agreement between aPS/PT IgG and IgM and high-risk aPL antibody profiles-especially the presence of lupus anticoagulant-has been demonstrated in a recent study of 95 well-characterized patients with primary antiphospholipid syndrome (75). Whereas the clinical implications of aPS/PT antibodies 
during viral infection remain to be comprehensively defined, we found here that IgG fractions containing high titers of these antibodies triggered NET release from neutrophils in vitro and accelerated thrombosis in vivo. Notably, IgG purified from COVID-19 patients with low aPS/PT serum titers demonstrated some activity in potentiating thrombosis (although high aPS/PT serum titer IgG fractions provided a more robust response). It is possible that aPL antibodies are but one species of a broader acute natural antibody response that is in fact prothrombotic in COVID-19 disease.

The orchestration of autoimmunity against phospholipids in COVID-19 is likely a complex interplay between genetic predisposition, historical antigen exposures, and a hyperactivated host immune response in the setting of a unique environmental trigger-infection with SARS-CoV-2 (76). It is not surprising that aPL antibodies of the IgM isotype (which are designed for rapid mobilization) predominate in our COVID19 patient cohort where they correlate with markers of neutrophil activation and NET release. The relationship between aPL antibodies and NETs in COVID-19 is potentially bidirectional. NETs are a known source of autoantigens, and cytokines released in parallel with NETosis may also facilitate NET-associated autoantibody propagation (77-80). An example of a cytokine that could play such a role is $B$ cell activating factor (BAFF), an important mediator of the maturation of $\mathrm{B}$ cells into antibody-producing cells (81). For example, neutrophil-derived BAFF likely participates in the production of anti-double-stranded DNA antibodies in lupus (78). In COVID-19, it is possible that production of aPL antibodies potentiates NET formation and BAFF release. This may further enhance the survival and differentiation of phospholipid-reactive B cells, and in some cases class-switching to the IgG isotype. The interplay between COVID-19 and humoral immunity is clearly an area that merits further study.

There are several potential clinical implications of these findings. Patients with catastrophic antiphospholipid syndrome are regularly treated with heparin, corticosteroids, and plasmapheresis (with the latter leading to a demonstrable improvement in outcomes) (82). Whereas both anticoagulation and corticosteroids have shown some promise to date in treatment of COVID-19, plasmapheresis has not been systematically explored. One wonders if this could provide benefit in the subgroup of COVID-19 patients with high titers of aPL antibodies. At the same time, convalescent plasma is receiving increasing attention as an approach to treating severe cases of COVID-19. Defining the extent to which convalescent plasma may contain aPL antibodies or other prothrombotic autoantibodies in addition to protective anti-SARS-CoV-2 antibodies, is another potential area for future investigation.

Our study has several limitations. We did not have access to the fresh plasma samples that would be required for lupus anticoagulant testing (which would have provided additional context and risk stratification for the aPL antibody profiling results). We speculate that some of the COVID-19 patients in our cohort whose serum samples were positive for aPS/PT antibodies would have displayed a lupus anticoagulant phenotype, as reported recently (26), but proving that will require further study and prospective access to plasma samples. We were also not able to define a clear link between circulating aPL antibodies and large artery/vein thrombosis in our patient cohort. Eleven patients in our cohort had thrombotic events and $55 \%$ of them were positive for aPL antibodies. Notably, aggressive anticoagulation has been regularly used at our institution in the context of COVID-19, and many COVID19 patients have been treated prophylactically with therapeutic doses of anticoagulants. It should also be noted that aPL antibodies were not tested on a defined day of hospitalization, but rather when a serum sample became available to the research laboratory. Future studies should endeavor to systematically track aPL antibodies over the full course of hospitalization of COVID-19 patients, and perhaps especially at and after the time of discharge.

As we await definitive antiviral and immunological solutions to the current COVID-19 pandemic, we posit that testing for aPL antibodies, including aPS/PT antibodies, may lead to improved risk stratification and personalization of treatment for patients with COVID-19. We also suggest further investigation of aPL antibodies as a contributor to the complex thrombo-inflammatory milieu of COVID-19.

\section{MATERIALS AND METHODS \\ Study design}

In this cross-sectional cohort study of 172 patients hospitalized with COVID-19, we aimed to measure subtypes of aPL antibodies in serum samples from these patients. We also asked whether purified IgG fractions from patients positive for serum aPL antibodies had prothrombotic properties in NET release assays in vitro and in two mouse models of venous thrombosis in vivo. In studies of the two mouse models of inferior vena cava thrombosis (the electrolysis and stenosis models), investigators doing the surgeries were blinded to the experimental conditions. No data points were excluded as outliers from either the human or mouse studies.

Our human cohort study complied with all relevant ethical regulations and was approved by the University of Michigan Institutional Review Board (HUM00179409), which waived the requirement for informed consent given the discarded nature of the serum samples.

Mice were housed in a specific pathogen-free barrier facility, and fed standard chow. Experimental protocols were approved by the University of Michigan Institutional Animal Care and Use Committee (PRO00008113), and all relevant ethical regulations were followed. Male $\mathrm{C} 57 \mathrm{BL} / 6$ mice were purchased from The Jackson Laboratory and used for 
experiments at 10-12 weeks of age.

\section{Serum samples from COVID-19 patients}

Serum samples from 172 hospitalized COVID-19 patients were used in this study (table S1). Blood was collected into serum separator tubes containing clot activator and serum separator gel by a trained hospital phlebotomist. After completion of biochemical testing ordered by the clinician, the remaining serum was stored for clinical testing at $4^{\circ} \mathrm{C}$ for up to 48 hours before release to the research laboratory. Serum samples were immediately divided into small aliquots and stored at $-80^{\circ} \mathrm{C}$ until the time of testing. All 172 patients had a confirmed COVID-19 diagnosis based on FDA-approved RNA testing. Fifty of these 172 patients were included in our prior study evaluating the role of NETs in COVID-19 (15). All patients were also included in our prior study evaluating the role of calprotectin in COVID-19 (16). However, aPL antibodies were not considered in either study $(15,16)$.

\section{Quantification of aPL antibodies}

aPL antibodies were quantified in sera using Quanta Lite ${ }^{\circledR}$ ACA IgG, ACA IgM, ACA IgA, $\beta_{2}$ GPI IgG, $\beta_{2}$ GPI IgM, $\beta_{2}$ GPI IgA, aPS IgG, aPS IgM, aPS/PT IgG, and aPS/PT IgM kits (Inova Diagnostics Inc.) according to the manufacturer's instructions. All assays are approved for clinical use and received $510(\mathrm{k})$ clearance from the FDA. Quanta Lite $^{\circledR}$ aPL antibody ELISAs (Inova Diagnostics) are well recognized by the international antiphospholipid syndrome research community and are utilized by the largest international antiphospholipid syndrome clinical research network registry, APS ACTION, in its core laboratories as the "gold standard" for aPL antibody testing $(83,84)$. Here, IgG, IgM, and IgA aCL antibody assays were reported in GPL, MPL, and APL units, respectively; a $\beta_{2}$ GPI antibody assays were reported in SGU, SMU, and SAU units; aPS assay were reported in GPS and MPS units; and aPS/PT antibody assays were reported in IgG and IgM units, all per the manufacturer's specifications. These various units are in accordance with the international consensus guidelines on aPL antibody testing from the $13^{\text {th }}$ International Congress on Antiphospholipid Antibodies (85). Per the manufacturer, the establishment of cut-off values for all Quanta Lite ${ }^{\circledR}$ aPL antibody assays are based on balancing sensitivity and specificity to achieve optimal clinical utility. For example, in the case of aPS/PT IgG/IgM (per the manufacturer's documentation), a total of 91 antiphospholipid syndrome patients, 247 healthy controls, and 43 diseased controls were tested. The threshold chosen resulted in a specificity of $99 \%$ for aPS/PT IgG and $98.7 \%$ for aPS/PT IgM. A previously described aPL Score was used to integrate summarize aPL antibodies profiles, with some adaptations (37). Here, aPL Score was calculated for each patient by adding points corresponding to the different type and titers of aPL antibodies, weighted as below: high-titer aCL IgG ( $\geq 40$ GPL) $=20$ points; low-titer aCL IgG $(\geq 20 \mathrm{GPL})=4$ points; aCL IgM $(\geq 20 \mathrm{MPL})=2$ points; high-titer $\mathrm{a}{ }_{2} \mathrm{PGI} \operatorname{IgG}(\geq 40 \mathrm{SGU})=20$ points; low-titer a $\beta_{2}$ PGI IgG ( $\geq 20$ SGU) $=6$ points; $a \beta_{2}$ PGI IgM ( $\geq 20$ SMU) $=1$ point; high-titer aPS/PT IgG ( $\geq 40$ units) $=20$ points; low-titer $\mathrm{aPS} / \mathrm{PT}$ IgG $(\geq 30$ units $)=13$ points; aPS/PT IgM ( $\geq 30$ units $)=8$ points.

\section{Quantification of S100A8/A9 (calprotectin)}

Calprotectin was measured with the Human S100A8/S100A9 Heterodimer DuoSet ELISA (DY8226-05, $\mathrm{R} \& \mathrm{D}$ Systems) according to the manufacturer's instructions.

\section{Quantification of myeloperoxidase-DNA complexes}

Myeloperoxidase (MPO)-DNA complexes were quantified similarly to what has been previously described (86). This protocol used several reagents from the Cell Death Detection ELISA kit (Roche). First, a high-binding EIA/RIA 96-well plate (Costar) was coated overnight at $4^{\circ} \mathrm{C}$ with anti-human myeloperoxidase antibody (Bio-Rad 0400-0002), diluted to a concentration of $1 \mu \mathrm{g} / \mathrm{ml}$ in coating buffer (Cell Death kit). The plate was washed two times with wash buffer $(0.05 \%$ Tween 20 in PBS), and then blocked with $4 \%$ bovine serum albumin in PBS (supplemented with $0.05 \%$ Tween 20 ) for 2 hours at room temperature. The plate was again washed five times, before incubating for $90 \mathrm{~min}$ at room temperature with $10 \%$ serum or plasma in the aforementioned blocking buffer (without Tween 20). The plate was washed five times, and then incubated for 90 min at room temperature with 10x anti-DNA antibody (HRP-conjugated; from the Cell Death kit) diluted 1:100 in blocking buffer. After five more washes, the plate was developed with 3,3' $, 5,5^{\prime}$-Tetramethylbenzidine (TMB) substrate (Invitrogen) followed by a $2 \mathrm{~N}$ sulfuric acid stop solution. Absorbance was measured at a wavelength of $450 \mathrm{~nm}$ using a Cytation 5 Cell Imaging Multi-Mode Reader (BioTek). Data were normalized to in vitro-prepared NET standards included on every plate, which were quantified based on their DNA content.

\section{Purification of human IgG fractions}

IgG was purified from COVID-19, APS, or control sera with a Protein G Agarose Kit following the manufacturer's instructions (Pierce). Briefly, serum was diluted in IgG binding buffer and passed through a Protein G Agarose column at least 5 times. IgG was then eluted with $0.1 \mathrm{M}$ glycine and then neutralized with $1 \mathrm{M}$ Tris. This was followed by overnight dialysis against $\mathrm{PBS}$ at $4^{\circ} \mathrm{C}$. IgG purity was verified with Coomassie staining, and concentrations were determined by BCA protein assay (Pierce) according to manufacturer's instructions. All IgG samples were determined to have endotoxin level below $0.1 \mathrm{EU} / \mathrm{ml}$ by the Pierce LAL Chromogenic Endotoxin Quantitation Kit (A39552) according to manufacturer's instructions. This Kit offers high sensitivity with linear detection range of 0.01-1.0 EU/mL.

Human neutrophil purification and NETosis assay

Collection of healthy human blood was approved by the 
University of Michigan IRB (HUM00044257). For neutrophil preparation, blood from healthy volunteers was collected into heparin tubes by standard phlebotomy techniques. The anticoagulated blood was then fractionated by density-gradient centrifugation using Ficoll-Paque Plus (GE Healthcare). Neutrophils were further purified by dextran sedimentation of the red blood cell layer, before lysing residual red blood cells with $0.2 \%$ sodium chloride. Neutrophil preparations were at least $95 \%$ pure as confirmed by both flow cytometry and nuclear morphology. To assess NETosis, complementary approaches were utilized. For the NET-associated MPO assay, neutrophils were resuspended in RPMI media (Gibco) supplemented with $0.5 \%$ bovine serum albumin (BSA, Sigma) and $0.5 \%$ fetal bovine serum (Gibco), which had been heatinactivated at $56^{\circ} \mathrm{C}$. Neutrophils ( $1 \times 10^{5} /$ well) were then incubated in 96 -well plates with $10 \mu \mathrm{g} / \mathrm{ml}$ human IgG for 3 hours. To collect NET-associated MPO, the culture media was discarded (to remove any soluble MPO) and replaced with 100 $\mu \mathrm{L}$ of RPMI supplemented with $5 \mathrm{U} / \mathrm{ml}$ Micrococcal nuclease (Thermo Fischer Scientific). After $10 \mathrm{~min}$ at $37^{\circ} \mathrm{C}$, digestion of NETs was stopped with $10 \mathrm{mM}$ EDTA. Supernatants were transferred to a v-shaped 96 well plate, and centrifuged at $350 \mathrm{xg}$ for $5 \mathrm{~min}$ to remove debris. Supernatants were then transferred into a new plate. To measure MPO activity, an equal volume of $3,3^{\prime}, 5,5^{\prime}$-Tetramethylbenzidine (TMB) substrate $\left(1 \mathrm{mg} \mathrm{ml}^{-1}\right.$, Thermo Fischer Scientific) was added to each well. After 10 min of incubation in the dark, the reaction was stopped by the addition of $50 \mu \mathrm{L}$ of $1 \mathrm{mM}$ sulfuric acid. Absorbance was measured at $450 \mathrm{~nm}$ using a Cytation 5 Cell Imaging Multi-Mode Reader. For immunofluorescence microscopy $1.5 \times 10^{5}$ neutrophils were seeded onto coverslips coated with $0.001 \%$ poly-L-lysine (Sigma) and fixed with $4 \%$ paraformaldehyde. In some experiments, cells were then permeabilized with $0.1 \%$ Triton-X for $15 \mathrm{~min}$ at room temperature. Blocking was with $1 \%$ bovine serum albumin. The primary antibody was against neutrophil elastase (Abcam 21595, diluted 1:100), and the FITC-conjugated secondary antibody was from SouthernBiotech (4052-02, diluted 1:250). DNA was stained with Hoechst 33342 (Invitrogen). Images were collected with a Cytation 5 Cell Imaging Multi-Mode Reader.

\section{Mouse models of venous thrombosis}

To model large-vein thrombosis, we employed procedures that we have utilized previously $(38,40,87)$. For the stenosis model, a laparotomy was performed under anesthesia. After exposure of the inferior vena cava, any lateral branches were ligated using 7-0 Prolene suture (back branches remained patent). A ligature was then fastened around the inferior vena cava over a blunted 30-gauge needle (which served as a spacer). After removal of the spacer, the abdomen was closed. Before recovery from anesthesia, mice received a single intravenous injection of human IgG $(500 \mu \mathrm{g}) .24$ hours later, mice were humanely euthanized, blood was collected, and thrombus characteristics were measured. The electrolytic model was performed as described (88). Briefly, after exposure of the inferior vena cava, any lateral branches were ligated using 7-0 Prolene suture (back branches remained patent). A 30-gauge silver-coated copper wire (KY-30-1-GRN, Electrospec) with exposed copper wire at the end was placed inside a 25-gauge needle, which was inserted into the inferior vena cava and positioned against the anterior wall (where it functioned as the anode). Another needle was implanted subcutaneously, completing the circuit (cathode). A constant current of $250 \mu \mathrm{A}$ was applied for $15 \mathrm{~min}$. The current was supplied by the voltage-to-current converter that is described in detail in the reference (88). After removal of the needle, the abdomen was closed. Before recovery from anesthesia, mice received a single intravenous injection of human IgG $(500 \mu \mathrm{g})$. 24 hours later, mice were humanely euthanized, blood was collected, and thrombus characteristics were measured.

\section{Western blotting}

Thrombi were homogenized in RIPA buffer with Roche protease inhibitor cocktail pellet and 1\% SDS. Protein was quantified using the BCA protein assay kit (Pierce). $30 \mu \mathrm{g}$ of protein was resolved by SDS-PAGE and then transferred to a PVDF membrane. Non-specific binding was blocked with $4 \%$ non-fat milk, followed by incubation with primary antibody directed against citrullinated histone H3 (Abcam 5103). Detection was with an HRP-labeled anti-rabbit secondary antibody and an HRP-labeled $\beta$-actin antibody, followed by detection using chemiluminescence.

\section{Thrombin generation assay}

Thrombin generation assays were performed using a previously described method (89).

\section{Statistical analysis}

Normally-distributed data were analyzed by two-sided $t$ test and skewed data were analyzed by Mann-Whitney test. Comparisons of more than two groups were analyzed by oneway ANOVA with correction for multiple comparisons by Dunnett's method. Data analysis was with GraphPad Prism software version 8 . Correlations were tested by Spearman's correlation coefficient. Statistical significance was defined as $\mathrm{p}<0.05$ unless stated otherwise.

\section{SUPPLEMENTARY MATERIALS}

stm.sciencemag.org/cgi/content/full/scitranslmed.abd3876/DC1

Table S1: Demographic and clinical characteristics of COVID-19 patient cohort

Table S2: Prevalence of aPL antibodies in serum from COVID-19 patients $(n=172)$ based on the first-available sample.

Fig S1: Testing for various aPL antibodies according to day of hospitalization.

Fig S2: Lack of association between aPS/PT antibodies and aPS antibodies in serum from COVID-19 patients.

Fig S3: A positive aPL antibody test is associated with greater neutrophil activation and worse kidney function.

Fig S4: Nadir eGFR in COVID-19 patients with or without a prior history of renal disease.

Fig S5: aPL antibody status as a predictor of oxygenation efficiency. 
Fig S6: aPL antibody status as a predictor of peak troponin and D-dimer. Fig S7: D-dimer plasma concentrations in patients with or without obesity. Fig S8: Determination of purity of IgG fractions from COVID-19 patients.

Fig S9: Dipyridamole suppresses IgG-induced NET release.

Fig S10: IgG from COVID-19 patients does not potentiate thrombin generation in cellfree pooled normal plasma.

Fig S11: Measurement of citrullinated histone $\mathrm{H} 3$ in mouse thrombi.

Data file S1: NET release measured by myeloperoxidase activity.

Data file S2: Thrombus length and weight in mice.

Data file S3: MPO-DNA in mice (stenosis and electrolysis models).

Data file S4: Thrombus length and weight in stenosis mouse model.

\section{REFERENCES AND NOTES}

1. C. Wu, X. Chen, Y. Cai, J. Xia, X. Zhou, S. Xu, H. Huang, L. Zhang, X. Zhou, C. Du, Y. Zhang, J. Song, S. Wang, Y. Chao, Z. Yang, J. Xu, X. Zhou, D. Chen, W. Xiong, L. Xu, F. Zhou, J. Jiang, C. Bai, J. Zheng, Y. Song, Risk Factors Associated With Acute Respiratory Distress Syndrome and Death in Patients With Coronavirus Disease 2019 Pneumonia in Wuhan, China. JAMA Intern. Med. 180, 934-943 (2020). doi:10.1001/jamainternmed.2020.0994 Medline

2. N. Tang, D. Li, X. Wang, Z. Sun, Abnormal coagulation parameters are associated with poor prognosis in patients with novel coronavirus pneumonia. J. Thromb. Haemost. 18, 844-847 (2020). doi:10.1111/ith.14768 Medline

3. W. J. Guan, Z. Y. Ni, Y. Hu, W. H. Liang, C. Q. Ou, J. X. He, L. Liu, H. Shan, C. L. Lei, D. S. C. Hui, B. Du, L. J. Li, G. Zeng, K. Y. Yuen, R. C. Chen, C. L. Tang, T. Wang, P. Y. Chen, J. Xiang, S. Y. Li, J. L. Wang, Z. J. Liang, Y. X. Peng, L. Wei, Y. Liu, Y. H. Hu, P. Peng, J. M. Wang, J. Y. Liu, Z. Chen, G. Li, Z. J. Zheng, S. Q. Qiu, J. Luo, C. J. Ye, S. Y. Zhu, N. S. Zhong; China Medical Treatment Expert Group for Covid-19, Clinical Characteristics of Coronavirus Disease 2019 in China. N. Engl. J. Med. 382, 17081720 (2020). doi:10.1056/NEJMoa2002032 Medline

4. N. Chen, M. Zhou, X. Dong, J. Qu, F. Gong, Y. Han, Y. Qiu, J. Wang, Y. Liu, Y. Wei, J. Xia, T. Yu, X. Zhang, L. Zhang, Epidemiological and clinical characteristics of 99 cases of 2019 novel coronavirus pneumonia in Wuhan, China: A descriptive study. Lancet 395, 507-513 (2020). doi:10.1016/S0140-6736(20)30211-7 Medline

5. F. Zhou, T. Yu, R. Du, G. Fan, Y. Liu, Z. Liu, J. Xiang, Y. Wang, B. Song, X. Gu, L. Guan, Y. Wei, H. Li, X. Wu, J. Xu, S. Tu, Y. Zhang, H. Chen, B. Cao, Clinical course and risk factors for mortality of adult inpatients with COVID-19 in Wuhan, China: A retrospective cohort study. Lancet 395, 1054-1062 (2020). doi:10.1016/S01406736(20)30566-3 Medline

6. T. Iba, J. H. Levy, T. E. Warkentin, J. Thachil, T. van der Poll, M. Levi; Scientific and Standardization Committee on DIC, and the Scientific and Standardization Committee on Perioperative and Critical Care of the International Society on Thrombosis and Haemostasis, Diagnosis and management of sepsis-induced coagulopathy and disseminated intravascular coagulation. J. Thromb. Haemost. 17, 1989-1994 (2019). doi:10.1111/ith.14578 Medline

7. T. Iba, M. Di Nisio, J. Thachil, H. Wada, H. Asakura, K. Sato, D. Saitoh, A Proposal of the Modification of Japanese Society on Thrombosis and Hemostasis (JSTH) Disseminated Intravascular Coagulation (DIC) Diagnostic Criteria for SepsisAssociated DIC. Clin. Appl. Thromb. Hemost. 24, 439-445 (2018). doi:10.1177/1076029617720069 Medline

8. S. Cui, S. Chen, X. Li, S. Liu, F. Wang, Prevalence of venous thromboembolism in patients with severe novel coronavirus pneumonia. J. Thromb. Haemost. 18, 14211424 (2020). doi:10.1111/ith.14830 Medline

9. F. A. Klok, M. J. H. A. Kruip, N. J. M. van der Meer, M. S. Arbous, D. A. M. P. J. Gommers, K. M. Kant, F. H. J. Kaptein, J. van Paassen, M. A. M. Stals, M. V. Huisman, H. Endeman, Incidence of thrombotic complications in critically ill ICU patients with COVID-19. Thromb. Res. 191, 145-147 (2020). doi:10.1016/i.thromres.2020.04.013 Medline

10. C. Lodigiani, G. Iapichino, L. Carenzo, M. Cecconi, P. Ferrazzi, T. Sebastian, N. Kucher, J. D. Studt, C. Sacco, B. Alexia, M. T. Sandri, S. Barco; Humanitas COVID19 Task Force, Venous and arterial thromboembolic complications in COVID-19 patients admitted to an academic hospital in Milan, Italy. Thromb. Res. 191, 9-14 (2020). doi:10.1016/i,thromres.2020.04.024 Medline

11. S. Tian, W. Hu, L. Niu, H. Liu, H. Xu, S. Y. Xiao, Pulmonary Pathology of Early-Phase 2019 Novel Coronavirus (COVID-19) Pneumonia in Two Patients With Lung Cancer. J. Thorac. Oncol. 15, 700-704 (2020). doi:10.1016/j.jtho.2020.02.010
Medline

12. Z. Xu, L. Shi, Y. Wang, J. Zhang, L. Huang, C. Zhang, S. Liu, P. Zhao, H. Liu, L. Zhu, Y. Tai, C. Bai, T. Gao, J. Song, P. Xia, J. Dong, J. Zhao, F. S. Wang, Pathological findings of COVID-19 associated with acute respiratory distress syndrome. Lancet Respir. Med. 8, 420-422 (2020). doi:10.1016/S2213-2600(20)30076-X Medline

13. S. E. Fox, A. Akmatbekov, J. L. Harbert, G. Li, J. Quincy Brown, R. S. Vander Heide, Pulmonary and cardiac pathology in African American patients with COVID-19: An autopsy series from New Orleans. Lancet Respir. Med. 8, 681-686 (2020). doi:10.1016/S2213-2600(20)30243-5 Medline

14. M. E. Colling, Y. Kanthi, COVID-19-associated coagulopathy: An exploration of mechanisms. Vasc. Med. 25, 471-478 (2020). doi:10.1177/1358863X20932640 Medline

15. Y. Zuo, S. Yalavarthi, H. Shi, K. Gockman, M. Zuo, J. A. Madison, C. Blair, A. Weber, B. J. Barnes, M. Egeblad, R. J. Woods, Y. Kanthi, J. S. Knight, Neutrophil extracellular traps in COVID-19. JCl Insight 5, 138999 (2020). doi:10.1172/jici.insight.138999 Medline

16. H. Shi, Y. Zuo, S. Yalavarthi, K. Gockman, M. Zuo, J. A. Madison, C. Blair, W. Woodward, S. P. Lezak, N. L. Lugogo, R. J. Woods, C. Lood, J. S. Knight, Y. Kanthi, Neutrophil calprotectin identifies severe pulmonary disease in COVID-19. J. Leukoc. Biol. JLB.3COVCRA0720-359R (2020) doi:10.1002/JLB.3COVCRA0720-359R Medline

17. B. J. Barnes, J. M. Adrover, A. Baxter-Stoltzfus, A. Borczuk, J. Cools-Lartigue, J. M. Crawford, J. Daßler-Plenker, P. Guerci, C. Huynh, J. S. Knight, M. Loda, M. R. Looney, F. McAllister, R. Rayes, S. Renaud, S. Rousseau, S. Salvatore, R. E. Schwartz, J. D. Spicer, C. C. Yost, A. Weber, Y. Zuo, M. Egeblad, Targeting potential drivers of COVID-19: Neutrophil extracellular traps. J. Exp. Med. 217, e20200652 (2020). doi:10.1084/jem.20200652 Medline

18. M. Leppkes, J. Knopf, E. Naschberger, A. Lindemann, J. Singh, I. Herrmann, M. Stürzl, L. Staats, A. Mahajan, C. Schauer, A. N. Kremer, S. Völkl, K. Amann, K. Evert, C. Falkeis, A. Wehrfritz, R. J. Rieker, A. Hartmann, A. E. Kremer, M. F. Neurath, L. E. Muñoz, G. Schett, M. Herrmann, Vascular occlusion by neutrophil extracellular traps in COVID-19. EBioMedicine 58, 102925 (2020). doi:10.1016/i.ebiom.2020.102925 Medline

19. E. A. Middleton, X. Y. He, F. Denorme, R. A. Campbell, D. Ng, S. P. Salvatore, M. Mostyka, A. Baxter-Stoltzfus, A. C. Borczuk, M. Loda, M. J. Cody, B. K. Manne, I. Portier, E. S. Harris, A. C. Petrey, E. J. Beswick, A. F. Caulin, A. Iovino, L. M. Abegglen, A. S. Weyrich, M. T. Rondina, M. Egeblad, J. D. Schiffman, C. C. Yost, Neutrophil extracellular traps contribute to immunothrombosis in COVID-19 acute respiratory distress syndrome. Blood 136, 1169-1179 (2020). doi:10.1182/blood.2020007008 Medline

20. L. Nicolai, A. Leunig, S. Brambs, R. Kaiser, T. Weinberger, M. Weigand, M. Muenchhoff, J. C. Hellmuth, S. Ledderose, H. Schulz, C. Scherer, M. Rudelius, M. Zoller, D. Höchter, O. Keppler, D. Teupser, B. Zwißler, M. von Bergwelt-Baildon, S. Kääb, S. Massberg, K. Pekayvaz, K. Stark, Immunothrombotic Dysregulation in COVID-19 Pneumonia Is Associated With Respiratory Failure and Coagulopathy. Circulation 142, 1176-1189 (2020). doi:10.1161/CIRCULATIONAHA.120.048488 Medline

21. J. A. Madison, A. Duarte-García, Y. Zuo, J. S. Knight, Treatment of thrombotic antiphospholipid syndrome in adults and children. Curr. Opin. Rheumatol. 32. 215-227 (2020). doi:10.1097/BOR.0000000000000702 Medline

22. Y. Zuo, H. Shi, C. Li, J. S. Knight, Antiphospholipid syndrome: A clinical perspective.

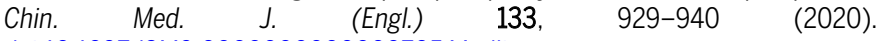
doi:10.1097/CM9.0000000000000705 Medline

23. S. Yalavarthi, T. J. Gould, A. N. Rao, L. F. Mazza, A. E. Morris, C. Núñez-Álvarez, D. Hernández-Ramírez, P. L. Bockenstedt, P. C. Liaw, A. R. Cabral, J. S. Knight, Release of neutrophil extracellular traps by neutrophils stimulated with antiphospholipid antibodies: A newly identified mechanism of thrombosis in the antiphospholipid syndrome. Arthritis Rheumatol. 67, 2990-3003 (2015). doi:10.1002/art.39247 Medline

24. N. M. Kazzaz, W. J. McCune, J. S. Knight, Treatment of catastrophic antiphospholipid syndrome. Curr. Opin. Rheumatol. 28, 218-227 (2016). doi:10.1097/BOR.0000000000000269 Medline

25. S. Miyakis, M. D. Lockshin, T. Atsumi, D. W. Branch, R. L. Brey, R. Cervera, R. H. Derksen, P. G. DE Groot, T. Koike, P. L. Meroni, G. Reber, Y. Shoenfeld, A. Tincani, P. G. Vlachoyiannopoulos, S. A. Krilis, International consensus statement on an 
update of the classification criteria for definite antiphospholipid syndrome (APS). J. Thromb. Haemost. 4, 295-306 (2006). doi:10.1111/i.1538-7836.2006.01753.x Medline

26. H. Shi, H. Zheng, Y. F. Yin, Q. Y. Hu, J. L. Teng, Y. Sun, H. L. Liu, X. B. Cheng, J. N. Ye, Y. T. Su, X. Y. Wu, J. F. Zhou, G. L. Norman, H. Y. Gong, X. M. Shi, Y. B. Peng, X. F. Wang, C. D. Yang, Antiphosphatidylserine/prothrombin antibodies (aPS/PT) as potential diagnostic markers and risk predictors of venous thrombosis and obstetric complications in antiphospholipid syndrome. Clin. Chem. Lab. Med. 56, 614-624 (2018). doi:10.1515/cclm-2017-0502 Medline

27. K. M. J. Devreese, E. A. Linskens, D. Benoit, H. Peperstraete, Antiphospholipid antibodies in patients with COVID-19: A relevant observation? J. Thromb. Haemost. 18, 2191-2201 (2020). doi:10.1111/ith.14994 Medline

28. Y. Zhang, M. Xiao, S. Zhang, P. Xia, W. Cao, W. Jiang, H. Chen, X. Ding, H. Zhao, H. Zhang, C. Wang, J. Zhao, X. Sun, R. Tian, W. Wu, D. Wu, J. Ma, Y. Chen, D. Zhang, J. Xie, X. Yan, X. Zhou, Z. Liu, J. Wang, B. Du, Y. Qin, P. Gao, X. Qin, Y. Xu, W. Zhang, T. Li, F. Zhang, Y. Zhao, Y. Li, S. Zhang, Coagulopathy and Antiphospholipid Antibodies in Patients with Covid-19. N. Engl. J. Med. 382, e38 (2020). doi:10.1056/NEJMc2007575 Medline

29. M. Gatto, C. Perricone, M. Tonello, O. Bistoni, A. M. Cattelan, R. Bursi, G. Cafaro, E. De Robertis, A. Mencacci, S. Bozza, A. Vianello, L. laccarino, R. Gerli, A. Doria, E. Bartoloni, Frequency and clinical correlates of antiphospholipid antibodies arising in patients with SARS-CoV-2 infection: Findings from a multicentre study on 122 cases. Clin. Exp. Rheumatol. 38, 754-759 (2020). Medline

30. V. Siguret, S. Voicu, M. Neuwirth, M. Delrue, E. Gayat, A. Stépanian, B. Mégarbane, Are antiphospholipid antibodies associated with thrombotic complications in critically ill COVID-19 patients? Thromb. Res. 195, 74-76 (2020). doi:10.1016/it.thromres.2020.07.016 Medline

31. M. Xiao, Y. Zhang, S. Zhang, X. Qin, P. Xia, W. Cao, W. Jiang, H. Chen, X. Ding, H. Zhao, H. Zhang, C. Wang, J. Zhao, X. Sun, R. Tian, W. Wu, D. Wu, J. Ma, Y. Chen, D. Zhang, J. Xie, X. Yan, X. Zhou, Z. Liu, J. Wang, B. Du, Y. Qin, P. Gao, M. Lu, X. Hou, X. Wu, H. Zhu, Y. Xu, W. Zhang, T. Li, F. Zhang, Y. Zhao, Y. Li, S. Zhang, Brief Report: Anti-phospholipid antibodies in critically ill patients with Coronavirus Disease 2019 (COVID-19). Arthritis Rheumatol. (2020).

32. M. O. Borghi, A. Beltagy, E. Garrafa, D. Curreli, G. Cecchini, C. Bodio, C. Grossi, S. Blengino, A. Tincani, F. Franceschini, L. Andreoli, M. G. Lazzaroni, S. Piantoni, S. Masneri, F. Crisafulli, D. Brugnoni, M. L. Muiesan, M. Salvetti, G. Parati, E. Torresani, M. Mahler, F. Heilbron, F. Pregnolato, M. Pengo, F. Tedesco, N. Pozzi, P. L. Meroni, Prevalence, specificity, and clinical association of anti-phospholipid antibodies in COVID-19 patients: are the antibodies really guilty? medRxiv, (2020).

33. N. Abdel-Wahab, S. Talathi, M. A. Lopez-Olivo, M. E. Suarez-Almazor, Risk of developing antiphospholipid antibodies following viral infection: A systematic review and meta-analysis. Lupus 27, 572-583 (2018). doi:10.1177/0961203317731532 Medline

34. R. A. Asherson, R. Cervera, 'Primary', 'secondary' and other variants of the antiphospholipid syndrome. Lupus 3, 293-298 (1994). doi:10.1177/096120339400300417 Medline

35. N. Abdel-Wahab, M. A. Lopez-Olivo, G. P. Pinto-Patarroyo, M. E. Suarez-Almazor, Systematic review of case reports of antiphospholipid syndrome following infection. Lupus 25, 1520-1531 (2016). doi:10.1177/0961203316640912 Medline

36. J. Sung, S. Anjum, Coronavirus Disease 2019 (COVID-19) Infection Associated With Antiphospholipid Antibodies and Four-Extremity Deep Vein thrombosis in a Previously Healthy Female. Cureus 12, e8408 (2020). doi:10.7759/cureus.8408 Medline

37. K. Otomo, T. Atsumi, O. Amengual, Y. Fujieda, M. Kato, K. Oku, T. Horita, S. Yasuda, T. Koike, Efficacy of the antiphospholipid score for the diagnosis of antiphospholipid syndrome and its predictive value for thrombotic events. Arthritis Rheum. 64, 504-512 (2012). doi:10.1002/art.33340 Medline

38. H. Meng, S. Yalavarthi, Y. Kanthi, L. F. Mazza, M. A. Elfline, C. E. Luke, D. J. Pinsky, P. K. Henke, J. S. Knight, In Vivo Role of Neutrophil Extracellular Traps in Antiphospholipid Antibody-Mediated Venous Thrombosis. Arthritis Rheumatol. 69, 655-667 (2017). doi:10.1002/art.39938 Medline

39. R. A. Ali, A. A. Gandhi, H. Meng, S. Yalavarthi, A. P. Vreede, S. K. Estes, O. R. Palmer, P. L. Bockenstedt, D. J. Pinsky, J. M. Greve, J. A. Diaz, Y. Kanthi, J. S. Knight, Adenosine receptor agonism protects against NETosis and thrombosis in antiphospholipid syndrome. Nat. Commun. 10, 1916 (2019). doi:10.1038/s41467- 019-09801-x Medline

40. J. S. Knight, H. Meng, P. Coit, S. Yalavarthi, G. Sule, A. A. Gandhi, R. C. Grenn, L. F. Mazza, R. A. Ali, P. Renauer, J. D. Wren, P. L. Bockenstedt, H. Wang, D. T. Eitzman, A. H. Sawalha, Activated signature of antiphospholipid syndrome neutrophils reveals potential therapeutic target. JCl Insight 2, e93897 (2017). doi:10.1172/jei.insight 93897 Medline

41. K. L. Allen, F. V. Fonseca, V. Betapudi, B. Willard, J. Zhang, K. R. McCrae, A novel pathway for human endothelial cell activation by antiphospholipid/anti- $\beta 2$ glycoprotein I antibodies. Blood 119, 884-893 (2012). doi:10.1182/blood-201103-344671 Medline

42. M. Galli, P. Comfurius, C. Maassen, H. C. Hemker, M. H. de Baets, P. J. van BredaVriesman, T. Barbui, R. F. Zwaal, E. M. Bevers, Anticardiolipin antibodies (ACA) directed not to cardiolipin but to a plasma protein cofactor. Lancet 335, 15441547 (1990). doi:10.1016/0140-6736(90)91374-J Medline

43. O. Amengual, T. Atsumi, T. Koike, Antiprothombin antibodies and the diagnosis of antiphospholipid syndrome. Clin. Immunol. 112, 144-149 (2004). doi:10.1016/i.clim.2004.02.013 Medline

44. P. Permpikul, L. V. Rao, S. I. Rapaport, Functional and binding studies of the roles of prothrombin and beta 2-glycoprotein I in the expression of lupus anticoagulant activity. Blood 83, 2878-2892 (1994). doi:10.1182/blood.V83.10.2878.2878 Medline

45. P. P. Chen, I. Giles, Antibodies to serine proteases in the antiphospholipid syndrome. Curr. Rheumatol. Rep. 12, 45-52 (2010). doi:10.1007/s11926-0090072-7 Medline

46. G. Cesarman-Maus, N. P. Ríos-Luna, A. B. Deora, B. Huang, R. Villa, Mdel. C. Cravioto, D. Alarcón-Segovia, J. Sánchez-Guerrero, K. A. Hajjar, Autoantibodies against the fibrinolytic receptor, annexin 2, in antiphospholipid syndrome. Blood 107, 4375-4382 (2006). doi:10.1182/blood-2005-07-2636 Medline

47. M. Blank, I. Krause, M. Fridkin, N. Keller, J. Kopolovic, I. Goldberg, A. Tobar, Y. Shoenfeld, Bacterial induction of autoantibodies to beta2-glycoprotein-l accounts for the infectious etiology of antiphospholipid syndrome. J. Clin. Invest. 109, 797804 (2002). doi:10.1172/JCl0212337 Medline

48. A. E. Gharavi, S. S. Pierangeli, R. G. Espinola, X. Liu, M. Colden-Stanfield, E. N. Harris, Antiphospholipid antibodies induced in mice by immunization with a cytomegalovirus-derived peptide cause thrombosis and activation of endothelial cells in vivo. Arthritis Rheum. 46, 545-552 (2002). doi:10.1002/art.10130 Medline

49. P. Cruz-Tapias, M. Blank, J. M. Anaya, Y. Shoenfeld, Infections and vaccines in the etiology of antiphospholipid syndrome. Curr. Opin. Rheumatol. 24, 389-393 (2012). doi:10.1097/BOR.0b013e32835448b8 Medline

50. R. Cervera, R. A. Asherson, M. L. Acevedo, J. A. Gómez-Puerta, G. Espinosa, G. De La Red, V. Gil, M. Ramos-Casals, M. García-Carrasco, M. Ingelmo, J. Font, Antiphospholipid syndrome associated with infections: Clinical and microbiological characteristics of 100 patients. Ann. Rheum. Dis. 63, 1312-1317 (2004). doi:10.1136/ard.2003.014175 Medline

51. P. G. de Groot, R. T. Urbanus, The significance of autoantibodies against $\beta 2$ glycoprotein I. Blood 120, 266-274 (2012). doi:10.1182/blood-2012-03-378646 Medline

52. M. L. Durkin, D. Marchese, M. D. Robinson, M. Ramgopal, Catastrophic antiphospholipid syndrome (CAPS) induced by influenza A virus subtype H1N1. BMJ Case Rep. 2013 (sep29 1), bcr2013200474 (2013). doi:10.1136/bcr-2013200474 Medline

53. J. E. Hunt, H. P. McNeil, G. J. Morgan, R. M. Crameri, S. A. Krilis, A phospholipidbeta 2-glycoprotein I complex is an antigen for anticardiolipin antibodies occurring in autoimmune disease but not with infection. Lupus 1, 75-81 (1992). doi:10.1177/096120339200100204 Medline

54. M. Blank, R. A. Asherson, R. Cervera, Y. Shoenfeld, Antiphospholipid syndrome infectious origin. J. Clin. Immunol. 24, 12-23 (2004). doi:10.1023/B:JOCl.0000018058.28764.ce Medline

55. M. Yamazaki, H. Asakura, Y. Kawamura, T. Ohka, M. Endo, T. Matsuda, Transient lupus anticoagulant induced by Epstein-Barr virus infection. Blood Coagul. Fibrinolysis 2, 771-774 (1991). doi:10.1097/00001721-199112000-00012 Medline

56. P. von Landenberg, H. W. Lehmann, S. Modrow, Human parvovirus B19 infection and antiphospholipid antibodies. Autoimmun. Rev. 6, 278-285 (2007). doi:10.1016/i.autrev.2006.09.006 Medline 
57. C. Catoggio, A. Alvarez-Uría, P. L. Fernandez, R. Cervera, G. Espinosa, Catastrophic antiphospholipid syndrome triggered by fulminant disseminated herpes simplex infection in a patient with systemic lupus erythematosus. Lupus 21, 1359-1361 (2012). doi:10.1177/0961203312458841 Medline

58. R. A. Asherson, R. Cervera, Antiphospholipid antibodies and infections. Ann. Rheum. Dis. 62, 388-393 (2003). doi:10.1136/ard.62.5.388 Medline

59. R. Cervera, I. Rodríguez-Pintó, G. Espinosa, The diagnosis and clinical management of the catastrophic antiphospholipid syndrome: A comprehensive review. J. Autoimmun. 92, 1-11 (2018). doi:10.1016/j.jaut.2018.05.007 Medline

60. I. Rodríguez-Pintó, M. Moitinho, I. Santacreu, Y. Shoenfeld, D. Erkan, G. Espinosa, R. Cervera; CAPS Registry Project Group (European Forum on Antiphospholipid Antibodies), Catastrophic antiphospholipid syndrome (CAPS): Descriptive analysis of 500 patients from the International CAPS Registry. Autoimmun. Rev. 15, 1120-1124 (2016). doi:10.1016/i.autrev.2016.09.010 Medline

61. S. Kapoor, A. Opneja, L. Nayak, The role of neutrophils in thrombosis. Thromb. Res. 170, 87-96 (2018). doi:10.1016/i.thromres.2018.08.005 Medline

62. C. Thålin, Y. Hisada, S. Lundström, N. Mackman, H. Wallén, Neutrophil Extracellular Traps: Villains and Targets in Arterial, Venous, and CancerAssociated Thrombosis. Arterioscler. Thromb. Vasc. Biol. 39, 1724-1738 (2019). doi:10.1161/ATVBAHA.119.312463 Medline

63. G. Sule, W. J. Kelley, K. Gockman, S. Yalavarthi, A. P. Vreede, A. L. Banka, P. L. Bockenstedt, 0. Eniola-Adefeso, J. S. Knight, Increased Adhesive Potential of Antiphospholipid Syndrome Neutrophils Mediated by $\beta 2$ Integrin Mac-1. Arthritis Rheumatol. 72, 114-124 (2020). doi:10.1002/art.41057 Medline

64. Y. Kanthi, J. S. Knight, Y. Zuo, D. J. Pinsky, New (re)purpose for an old drug: Purinergic modulation may extinguish the COVID-19 thromboinflammatory firestorm. JCI Insight 5, e140971 (2020). doi:10.1172/jci.insight.140971 Medline

65. X. Liu, Z. Li, S. Liu, J. Sun, Z. Chen, M. Jiang, Q. Zhang, Y. Wei, X. Wang, Y. Y. Huang, Y. Shi, Y. Xu, H. Xian, F. Bai, C. Ou, B. Xiong, A. M. Lew, J. Cui, R. Fang, H. Huang, J. Zhao, X. Hong, Y. Zhang, F. Zhou, H. B. Luo, Potential therapeutic effects of dipyridamole in the severely ill patients with COVID-19. Acta Pharm. Sin. B 10 , 1205-1215 (2020). Medline

66. M. G. Tektonidou, L. Andreoli, M. Limper, Z. Amoura, R. Cervera, N. CostedoatChalumeau, M. J. Cuadrado, T. Dörner, R. Ferrer-Oliveras, K. Hambly, M. A. Khamashta, J. King, F. Marchiori, P. L. Meroni, M. Mosca, V. Pengo, L. Raio, G. RuizIrastorza, Y. Shoenfeld, L. Stojanovich, E. Svenungsson, D. Wahl, A. Tincani, M. M. Ward, EULAR recommendations for the management of antiphospholipid syndrome in adults. Ann. Rheum. Dis. 78, 1296-1304 (2019). doi:10.1136/annrheumdis-2019-215213 Medline

67. D. G. Wahl, F. Guillemin, E. de Maistre, C. Perret-Guillaume, T. Lecompte, G. Thibaut, Meta-analysis of the risk of venous thrombosis in individuals with antiphospholipid antibodies without underlying autoimmune disease or previous thrombosis. Lupus 7, 15-22 (1998). doi:10.1191/096120398678919688 Medline

68. M. Galli, D. Luciani, G. Bertolini, T. Barbui, Lupus anticoagulants are stronger risk factors for thrombosis than anticardiolipin antibodies in the antiphospholipid syndrome: A systematic review of the literature. Blood 101, 1827-1832 (2003). doi:10.1182/blood-2002-02-0441 Medline

69. Q. Reynaud, J. C. Lega, P. Mismetti, C. Chapelle, D. Wahl, P. Cathébras, S. Laporte, Risk of venous and arterial thrombosis according to type of antiphospholipid antibodies in adults without systemic lupus erythematosus: A systematic review and meta-analysis. Autoimmun. Rev. 13, 595-608 (2014). doi:10.1016/i.autrev.2013.11.004 Medline

70. D. G. Wahl, F. Guillemin, E. de Maistre, C. Perret, T. Lecompte, G. Thibaut, Risk for venous thrombosis related to antiphospholipid antibodies in systemic lupus erythematosus-A meta-analysis. Lupus 6, 467-473 (1997). doi:10.1177/096120339700600510 Medline

71. N. Heikal, T. B. Martins, S. K. White, R. Willis, D. Ware Branch, R. L. Schmidt, A. E. Tebo, Laboratory Evaluation of Antiphospholipid Syndrome. Am. J. Clin. Pathol. 152, 638-646 (2019). Medline

72. G. R. Hughes, M. A. Khamashta, Seronegative antiphospholipid syndrome. Ann. Rheum. Dis. 62, 1127 (2003). doi:10.1136/ard.2003.006163 Medline

73. N. J. Sweiss, R. Bo, R. Kapadia, D. Manst, F. Mahmood, T. Adhikari, S. Volkov, M. Badaracco, M. Smaron, A. Chang, J. Baron, J. S. Levine, IgA anti-beta2glycoprotein I autoantibodies are associated with an increased risk of thromboembolic events in patients with systemic lupus erythematosus. PLOS
ONE 5, e12280 (2010). doi:10.1371/journal.pone.0012280 Medline

74. S. Sciascia, G. Sanna, V. Murru, D. Roccatello, M. A. Khamashta, M. L. Bertolaccini, Anti-prothrombin (aPT) and anti-phosphatidylserine/prothrombin (aPS/PT) antibodies and the risk of thrombosis in the antiphospholipid syndrome. A systematic review. Thromb. Haemost. 111, 354-364 (2014). doi:10.1160/TH1306-0509 Medline

75. C. A. Núñez-Álvarez, G. Hernández-Molina, P. Bermúdez-Bermejo, V. ZamoraLegoff, D. F. Hernández-Ramírez, E. Olivares-Martínez, A. R. Cabral, Prevalence and associations of anti-phosphatidylserine/prothrombin antibodies with clinical phenotypes in patients with primary antiphospholipid syndrome: aPS/PT antibodies in primary antiphospholipid syndrome. Thromb. Res. 174, 141-147 (2019). doi:10.1016/i.thromres.2018.12.023 Medline

76. M. Ehrenfeld, A. Tincani, L. Andreoli, M. Cattalini, A. Greenbaum, D. Kanduc, J. Alijotas-Reig, V. Zinserling, N. Semenova, H. Amital, Y. Shoenfeld, Covid-19 and autoimmunity. Autoimmun. Rev. 19, $102597 \quad$ (2020). doi:10.1016/i.autrev.2020.102597 Medline

77. K. H. Lee, A. Kronbichler, D. D. Park, Y. Park, H. Moon, H. Kim, J. H. Choi, Y. Choi, S. Shim, I. S. Lyu, B. H. Yun, Y. Han, D. Lee, S. Y. Lee, B. H. Yoo, K. H. Lee, T. L. Kim, H. Kim, J. S. Shim, W. Nam, H. So, S. Choi, S. Lee, J. I. Shin, Neutrophil extracellular traps (NETs) in autoimmune diseases: A comprehensive review. Autoimmun. Rev. 16, 1160-1173 (2017). doi:10.1016/i.autrev.2017.09.012 Medline

78. I. Jeremic, O. Djuric, M. Nikolic, M. Vlajnic, A. Nikolic, D. Radojkovic, B. BonaciNikolic, Neutrophil extracellular traps-associated markers are elevated in patients with systemic lupus erythematosus. Rheumatol. Int. 39, 1849-1857 (2019). doi:10.1007/s00296-019-04426-1 Medline

79. M. Steri, V. Orrù, M. L. Idda, M. Pitzalis, M. Pala, I. Zara, C. Sidore, V. Faà, M. Floris, M. Deiana, I. Asunis, E. Porcu, A. Mulas, M. G. Piras, M. Lobina, S. Lai, M. Marongiu, V. Serra, M. Marongiu, G. Sole, F. Busonero, A. Maschio, R. Cusano, G. Cuccuru, F. Deidda, F. Poddie, G. Farina, M. Dei, F. Virdis, S. Olla, M. A. Satta, M. Pani, A. Delitala, E. Cocco, J. Frau, G. Coghe, L. Lorefice, G. Fenu, P. Ferrigno, M. Ban, N. Barizzone, M. Leone, F. R. Guerini, M. Piga, D. Firinu, I. Kockum, I. Lima Bomfim, T. Olsson, L. Alfredsson, A. Suarez, P. E. Carreira, M. J. Castillo-Palma, J. H. Marcus, M. Congia, A. Angius, M. Melis, A. Gonzalez, M. E. Alarcón Riquelme, B. M. da Silva, M. Marchini, M. G. Danieli, S. Del Giacco, A. Mathieu, A. Pani, S. B. Montgomery, G. Rosati, J. Hillert, S. Sawcer, S. D'Alfonso, J. A. Todd, J. Novembre, G. R. Abecasis, M. B. Whalen, M. G. Marrosu, A. Meloni, S. Sanna, M. Gorospe, D. Schlessinger, E. Fiorillo, M. Zoledziewska, F. Cucca, Overexpression of the Cytokine BAFF and Autoimmunity Risk. N. Engl. J. Med. 376, 1615-1626 (2017). doi:10.1056/NEJMoa1610528 Medline

80. C. Lood, G. C. Hughes, Neutrophil extracellular traps as a potential source of autoantigen in cocaine-associated autoimmunity. Rheumatology (Oxford) 56 , 638-643 (2017). Medline

81. S. W. Jackson, A. Davidson, BAFF inhibition in SLE-Is tolerance restored? Immunol. Rev. 292, 102-119 (2019). doi:10.1111/imr.12810 Medline

82. S. Bucciarelli, G. Espinosa, R. Cervera, D. Erkan, J. A. Gómez-Puerta, M. RamosCasals, J. Font, R. A. Asherson; European Forum on Antiphospholipid Antibodies, Mortality in the catastrophic antiphospholipid syndrome: Causes of death and prognostic factors in a series of 250 patients. Arthritis Rheum. 54, 2568-2576 (2006). doi:10.1002/art.22018 Medline

83. D. Erkan, M. D. Lockshin; APS ACTION members, APS ACTION-AntiPhospholipid Syndrome Alliance For Clinical Trials and InternatiOnal Networking. Lupus 21, 695-698 (2012). doi:10.1177/0961203312437810 Medline

84. S. Sciascia, R. Willis, V. Pengo, S. Krilis, D. Andrade, M. G. Tektonidou, A. Ugarte, C. Chighizola, D. W. Branch, R. A. Levy, C. Nalli, P. R. Fortin, M. Petri, E. Rodriguez, I. Rodriguez-Pinto, T. Atsumi, I. Nascimento, R. Rosa, A. Banzato, D. Erkan, H. Cohen, M. Efthymiou, I. Mackie, M. L. Bertolaccini; APS ACTION, The comparison of real world and core laboratory antiphospholipid antibody ELISA results from antiphospholipid syndrome alliance for clinical trials \& international networking (APS ACTION) clinical database and repository analysis. Thromb. Res. 175, 32-36 (2019). doi:10.1016/j.thromres.2019.01.010 Medline

85. G. Lakos, E. J. Favaloro, E. N. Harris, P. L. Meroni, A. Tincani, R. C. Wong, S. S. Pierangeli, International consensus guidelines on anticardiolipin and anti- $\beta 2$ glycoprotein I testing: Report from the 13th International Congress on Antiphospholipid Antibodies. Arthritis Rheum. 64, 1-10 (2012). doi:10.1002/art.33349 Medline 
86. K. Kessenbrock, M. Krumbholz, U. Schönermarck, W. Back, W. L. Gross, Z. Werb, H. J. Gröne, V. Brinkmann, D. E. Jenne, Netting neutrophils in autoimmune smallvessel vasculitis. Nat. Med. 15, 623-625 (2009). doi:10.1038/nm.1959 Medline

87. V. Yadav, L. Chi, R. Zhao, B. E. Tourdot, S. Yalavarthi, B. N. Jacobs, A. Banka, H. Liao, S. Koonse, A. C. Anyanwu, S. H. Visovatti, M. A. Holinstat, J. M. Kahlenberg, J. S. Knight, D. J. Pinsky, Y. Kanthi, Ectonucleotidase tri(di)phosphohydrolase-1 (ENTPD-1) disrupts inflammasome/interleukin 1 $\beta$-driven venous thrombosis. J. Clin. Invest. 129, 2872-2877 (2019). doi:10.1172/JC1124804 Medline

88. O. R. Palmer, M. E. Shaydakov, J. P. Rainey, D. A. Lawrence, J. M. Greve, J. A. Diaz, Update on the electrolytic IVC model for pre-clinical studies of venous thrombosis. Res. Pract. Thromb. Haemost. 2, 266-273 (2018). doi:10.1002/rth2.12074 Medline

89. D. A. Slatter, C. L. Percy, K. Allen-Redpath, J. M. Gajsiewicz, N. J. Brooks, A. Clayton, V. J. Tyrrell, M. Rosas, S. N. Lauder, A. Watson, M. Dul, Y. Garcia-Diaz, M. Aldrovandi, M. Heurich, J. Hall, J. H. Morrissey, S. Lacroix-Desmazes, S. Delignat, P. V. Jenkins, P. W. Collins, V. B. O'Donnell, Enzymatically oxidized phospholipids restore thrombin generation in coagulation factor deficiencies. $\mathrm{JCl}$ Insight 3 , e98459 (2018). doi:10.1172/jci.insight.98459 Medline

Acknowledgments: Funding: This work was supported by a grant from the Burroughs Wellcome Fund to JSK and grants from the Michigan Medicine Frankel Cardiovascular Center and A. Alfred Taubman Medical Research Institute to YK and JSK. YZ was supported by a career development grant from the Rheumatology Research Foundation. JAM was partially supported by the VA Healthcare System. JHM and SAS were supported by NIH grant R35 HL135823. YK was supported by the NIH/NHLBI Intramural Research Program, Lasker Foundation, NIH (K08HL131993, R01HL150392), Falk Medical Research Trust Catalyst Award, and the JOBST-American Venous Forum Award. JSK was supported by grants from the NIH (R01HL115138) and Lupus Research Alliance. Author contributions: YZ, SY, HS, GS, KG, JAM, and MZ conducted experiments and analyzed data related to measurement of aPL antibodies in serum and correlation of these measurements with clinical data. RAA and SY performed and analyzed data related to in vitro NET release. SKE, RAA, and AAG performed and analyzed data related to mouse surgical experiments. VY and JW performed and analyzed data related to Western blotting on mouse thrombi. SAS performed thrombin generation experiments, and SAS and JHM analyzed these data. WW, SPL, and NLL participated in serum sample acquisition. YZ, YK, and JSK participated in analysis of all data and conceived the study. All authors participated in writing of the manuscript and approved the final version. Competing interests: $Y Z$ holds a grant for preclinical studies from Pfizer. YK has received consulting fees from Surface Oncology, and has a pending patent on the use of biogases in vascular disease. JSK holds a grant for preclinical studies from Jazz Pharmaceuticals. Data and Materials Availability: All data associated with this study are in the main text or supplementary materials. This work is licensed under a Creative Commons Attribution 4.0 International (CC BY 4.0) license, which permits unrestricted use, distribution, and reproduction in any medium, provided the original work is properly cited. To view a copy of this license, visit https://creativecommons.org/licenses/by/4.0/. This license does not apply to figures/photos/artwork or other content included in the article that is credited to a third party; obtain authorization from the rights holder before using this material.

Submitted 18June 2020

Accepted 30 October 2020

Published First Release 2 November 2020

10.1126/scitranslmed.abd3876 

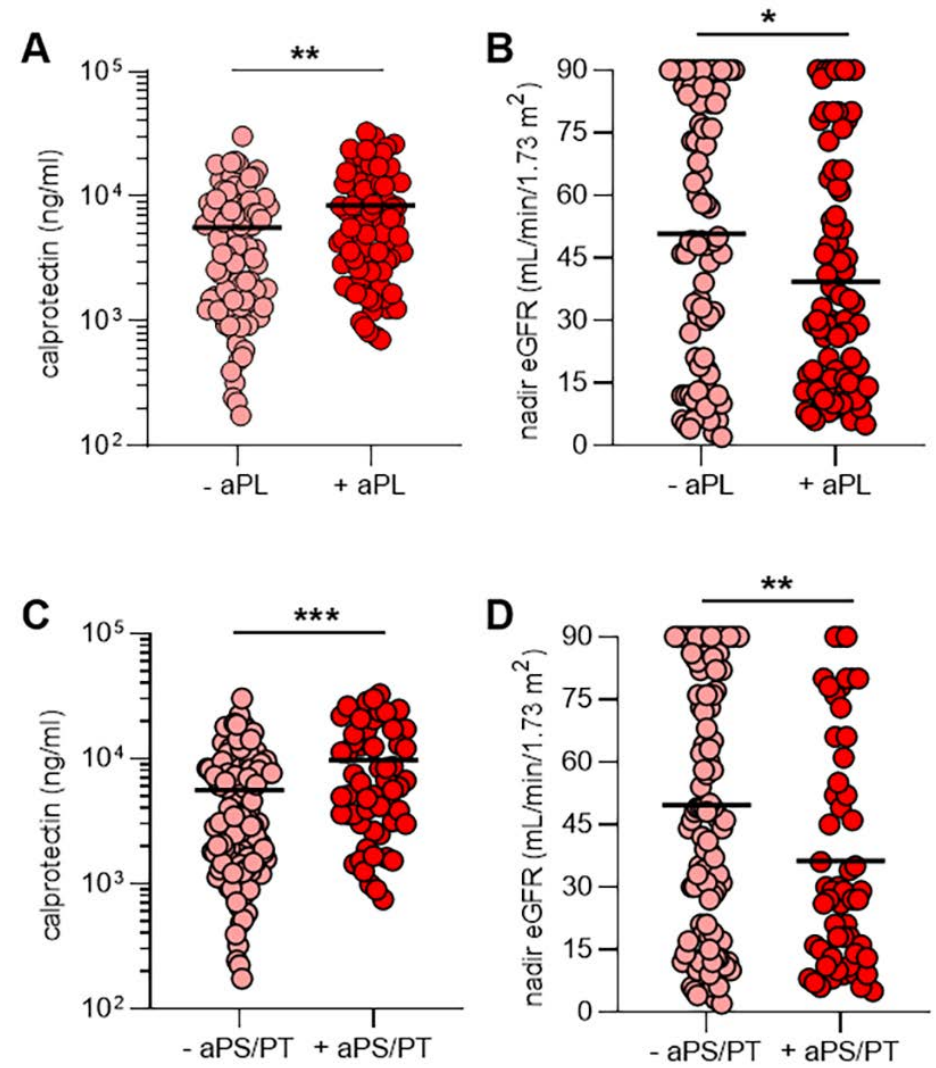

Fig. 1. aPL antibodies, NET release, and renal function. Serum samples were obtained from 172 patients hospitalized with COVID-19. (A, B) Patients were divided into two groups based on whether their serum samples were positive (+) or negative (-) for the presence of aPL antibodies (positivity was based on the manufacturer's threshold). Shown is the amount of calprotectin in serum, a measure of neutrophil activation (A), and the clinical estimated glomerular filtration rate (eGFR) (B) for the two groups. (C, D) Patients were divided into two groups based on whether their serum samples were positive $(+)$ or negative (-) for the presence of aPS/PT antibodies (IgG and IgM considered together); manufacturer's thresholds were used to determine positivity. Shown is the amount of calprotectin (C) and the eGFR (D) for the two groups. Groups were analyzed by an unpaired $t$ test: ${ }^{*} p<0.05$, ${ }^{* *} p<0.01$, and ${ }^{* *} p<0.001$. Horizontal black bars represent the mean. For patients who had serum samples available at multiple time points, only the first-available serum sample was used in this analysis. 


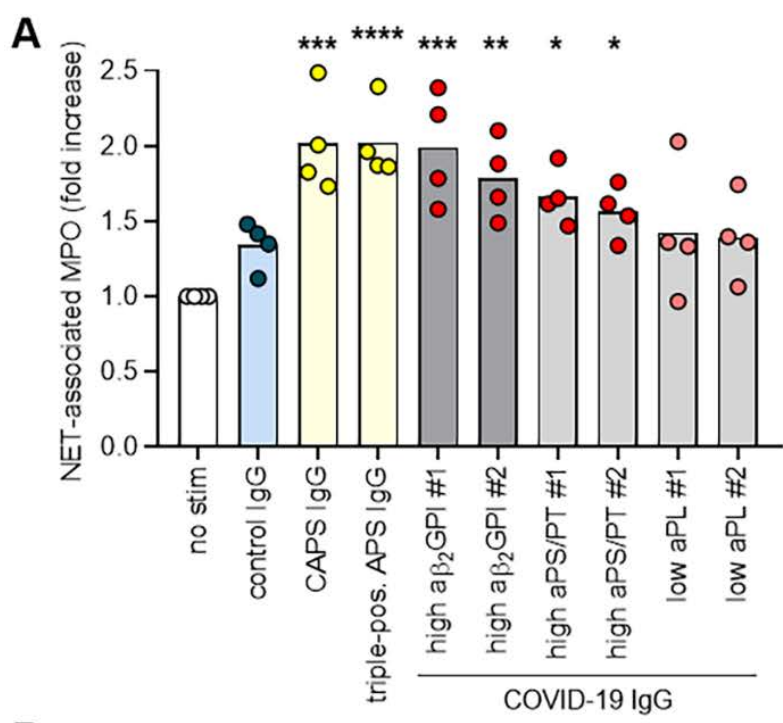

B
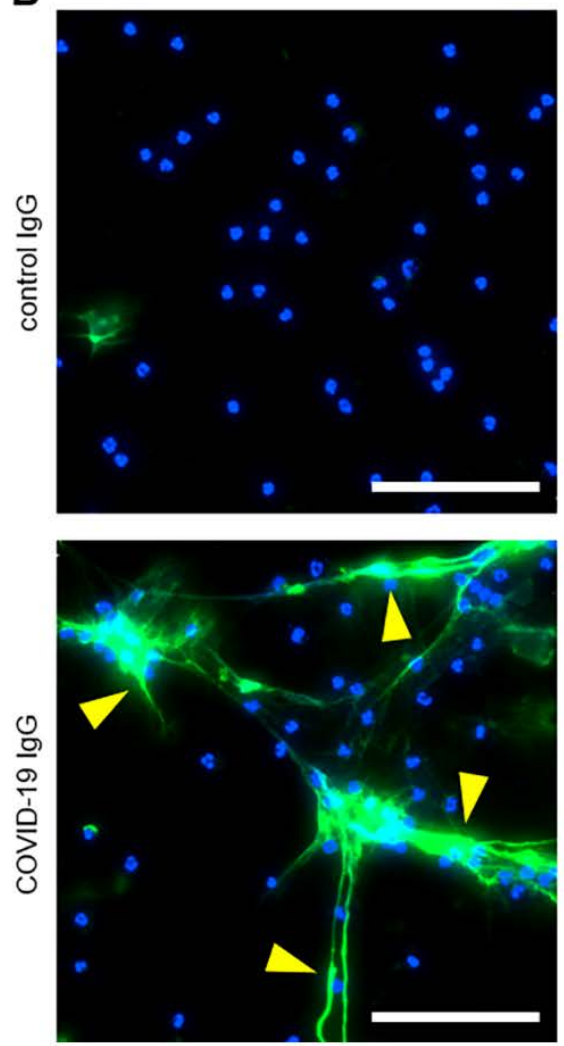

Fig. 2. COVID-19 patient IgG promotes NET release from normal neutrophils in vitro. (A) Control neutrophils were isolated from healthy individuals and cultured in the presence of human IgG $(10 \mu \mathrm{g} / \mathrm{ml})$ for 3 hours. IgG fractions were obtained from COVID-19 patients who were or were not positive for $\mathrm{aPL}$ antibodies (aPS/PT or $\mathrm{a} \beta_{2} \mathrm{GPI}$ as indicated), and from patients with antiphospholipid syndrome (APS) or catastrophic antiphospholipid syndrome (CAPS). NET release was measured by the enzymatic activity of myeloperoxidase (MPO) after solubilization of NETs with micrococcal nuclease; fold increase is plotted relative to unstimulated neutrophils. Data are derived from four independent experiments. Comparisons were by one-way ANOVA with correction for multiple comparisons by Dunnett's method: $\quad{ }^{*} p<0.05, \quad * * p<0.01$, $*^{* *} p<0.001$. (B) Representative images show released NETs, indicated by yellow arrows. DNA, blue; neutrophil elastase, green. Scale bar,100 microns. 


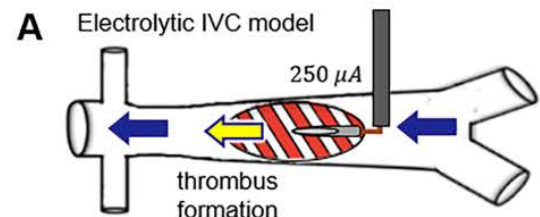

B

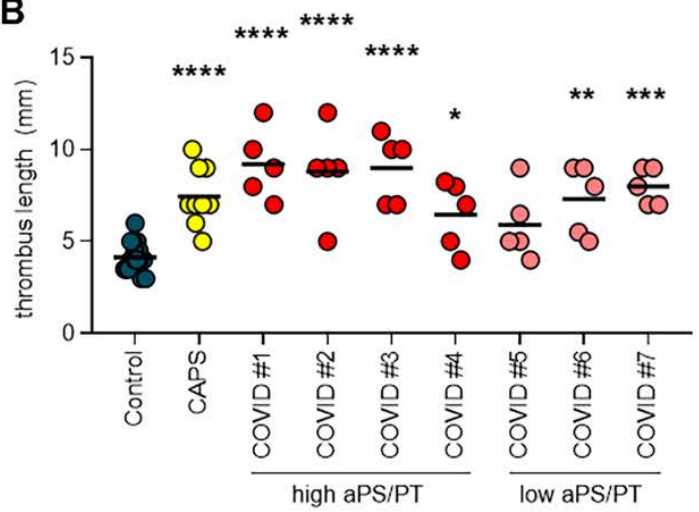

C

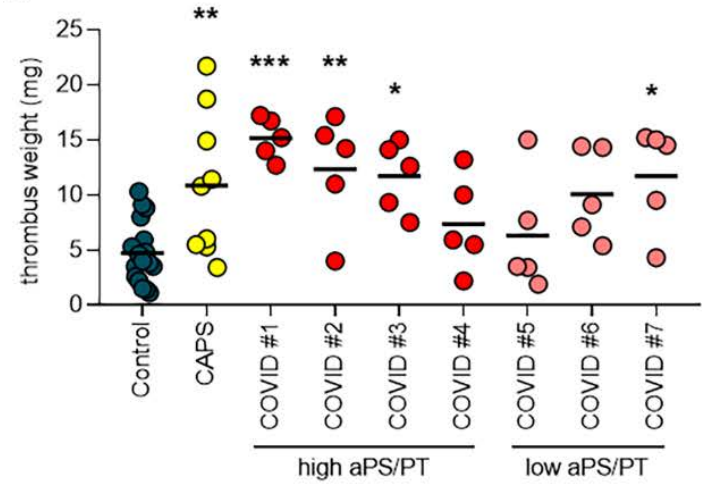

D

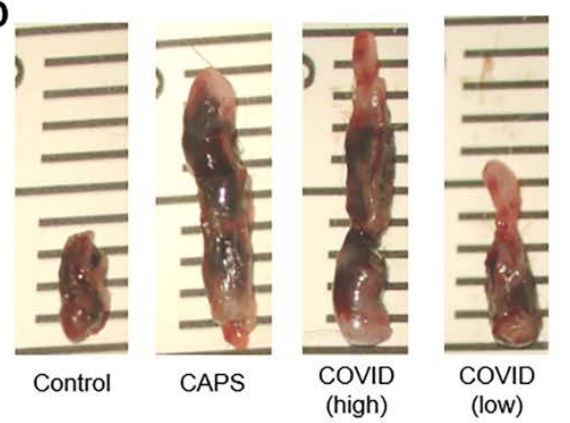

G

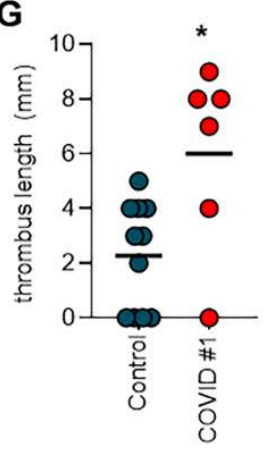

E
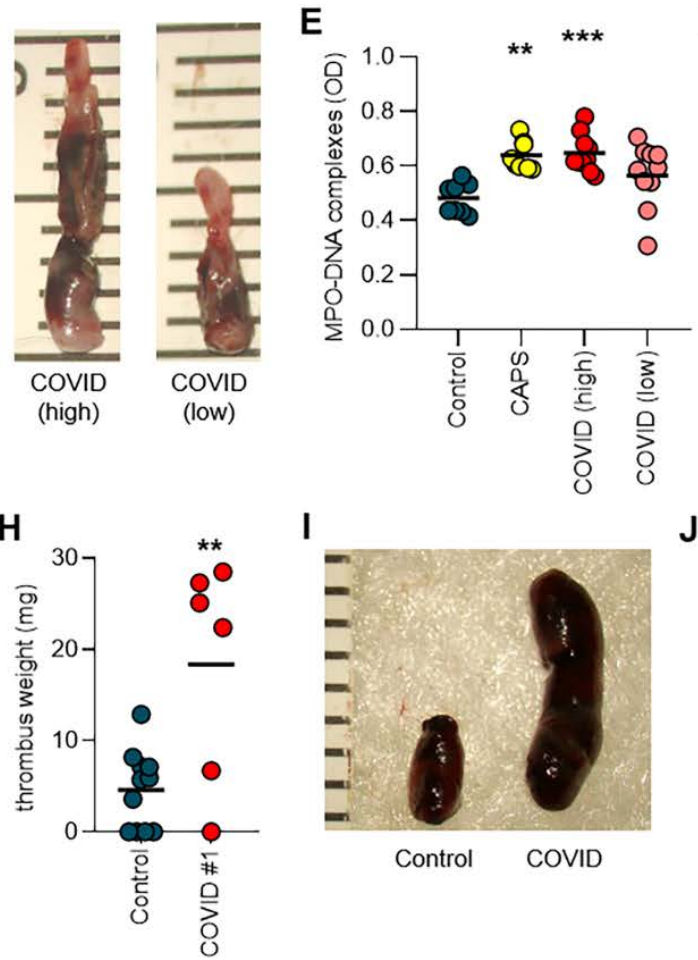

I

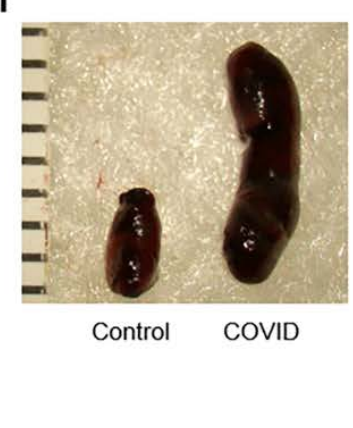

F Stenosis Stenosis
IVC model 7-0 suture

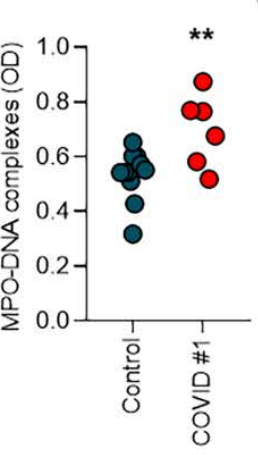

Fig. 3. IgG from COVID19 patients potentiates thrombosis in mice. (A) Schematic shows thrombus initiation in the inferior vena cava (IVC) of mice by local electrolysis leading to free radical generation and activation of the endothelium. (B, C) Mice were administered IgG from healthy individuals (control), from patients with COVID-19 who had high or low aPS/PT antibodies or from patients with catastrophic

antiphospholipid

syndrome (CAPS). Just prior to intravenous administration of IgG, mice were subjected to local electrolysis in the inferior vena cava. Thrombus length (B) and weight (C) were determined 24 hours after IgG injection. Scatter plots with individual data points (each point represents a single mouse) are presented. (D) Shown are photographs of representative thrombi from the experiments presented in panels $B$ and C. (E) Serum samples from mice in the experiments presented in panels $B$ and $C$ were

tested for NET remnants measured by an ELISA that detected myeloperoxidase (MPO)-DNA complexes. Scatter plots with individual data points (each point represents a single mouse) are presented. OD, optical density. (F) Schematic shows thrombus initiation in the inferior vena cava (IVC) of mice by stenosis that was induced via placement of a fixed suture over a spacer that was subsequently removed. $(G, H)$ Mice were treated intravenously with IgG from a healthy individual (control) or from a patient with COVID-19 with high aPS/PT antibodies. Just prior to intravenous administration of IgG, stenosis was induced. 24 hours later thrombus length $(G)$ and weight $(H)$ were determined. Scatter plots with individual data points (each point represents a single mouse) are presented. (I) Shown are photographs of representative thrombi from the experiments presented in panels $\mathrm{G}$ and $\mathrm{H}$. (J) Serum samples from mice in the experiments presented in panels $\mathrm{G}$ and $\mathrm{H}$ were tested for NET remnants measured by an ELISA that detected MPO-DNA complexes. Scatter plots with individual data points (each point represents a single mouse) are presented. OD, optical density. Horizontal black bars represent the mean. Comparisons were by either one-way ANOVA with correction for multiple comparisons by Dunnett's method (B, C, E) or unpaired $t$ test (G, $\mathrm{H}, \mathrm{J}){ }^{*} \mathrm{p}<0.05,{ }^{* *} \mathrm{p}<0.01,{ }^{* * *} \mathrm{p}<0.001$, and ${ }^{* * * *} \mathrm{p}<0.0001$. 
Table 1. Prevalence of antiphospholipid antibodies in serum from COVID-19 patients (n=172)

\begin{tabular}{lcccc}
\hline aPL antibody & $\begin{array}{c}\text { Number positive } \\
\text { (manufacturer's cut-off) }\end{array}$ & $\mathbf{\%}$ & $\begin{array}{c}\text { Number positive } \\
\text { (titer } \geq \mathbf{4 0} \text { units) }\end{array}$ & $\mathbf{\%}$ \\
\hline aCL IgG & 8 & $4.7 \%$ & 2 & $1.2 \%$ \\
aCL IgM & 39 & $23 \%$ & 13 & $7.6 \%$ \\
aCL IgA & 6 & $3.5 \%$ & 1 & $0.58 \%$ \\
a $\beta_{2}$ GPI IgG & 5 & $2.9 \%$ & 3 & $1.7 \%$ \\
$a{ }_{2}$ GPI IgM & 9 & $5.2 \%$ & 7 & $4.1 \%$ \\
a ${ }_{2}$ GPI IgA & 7 & $4.1 \%$ & 3 & $1.7 \%$ \\
aPS/PT IgG & 42 & $24 \%$ & 21 & $12 \%$ \\
aPS/PT IgM & 31 & $18 \%$ & 21 & $12 \%$ \\
any positive aPL & 89 & $52 \%$ & 52 & $30 \%$ \\
\hline
\end{tabular}

aPL antibody, antiphospholipid autoantibodies; aCL, anticardiolipin antibodies; a $\beta_{2}$ GPI, anti-beta-2 glycoprotein I antibodies; aPS/PT, anti-phosphatidylserine/prothrombin antibodies;

Manufacturer's cut-off: aCL IgG, IgM, IgA = 20 IgG, IgM, IgA phospholipid units; a $\beta_{2} \mathrm{GPI}$ IgG, IgM, IgA = 20 standard IgG, IgM, IgA units; aPS/PT IgG, IgM = 30 units 
Table 2. Correlation of antiphospholipid antibodies with clinical and laboratory variables in COVID-19 patients ${ }^{\ddagger}$

\begin{tabular}{|c|c|c|c|c|c|c|c|c|c|c|c|c|c|c|}
\hline \multirow[b]{2}{*}{ Spearman } & \multicolumn{2}{|c|}{$\begin{array}{l}\text { aPL Score } \\
\text { (modified) }\end{array}$} & \multicolumn{2}{|c|}{ aCL IgG } & \multicolumn{2}{|c|}{ aCL IgM } & \multicolumn{2}{|c|}{$\mathbf{a} \beta_{2} G P I$ IgG } & \multicolumn{2}{|c|}{$\mathbf{a} \beta_{2} G P I$ IgM } & \multicolumn{2}{|c|}{ aPS/PT IgG } & \multicolumn{2}{|c|}{ aPS/PT IgM } \\
\hline & $\mathrm{r}$ & $\mathrm{p}$ & $\mathrm{r}$ & $\mathrm{p}$ & $\mathrm{r}$ & $\mathrm{p}$ & $\mathrm{r}$ & $\mathrm{p}$ & $\mathrm{r}$ & $\mathrm{p}$ & $\mathrm{r}$ & $\mathrm{p}$ & r & $\mathrm{p}$ \\
\hline \multicolumn{15}{|c|}{ Clinical and lab variables } \\
\hline SpO2/FiO2 & -0.051 & ns & -0.16 & $*$ & -0.19 & $*$ & -0.10 & ns & -0.022 & ns & -0.11 & ns & -0.16 & $*$ \\
\hline C-reactive protein & 0.031 & ns & 0.15 & ns & 0.17 & $*$ & 0.075 & ns & -0.040 & ns & 0.058 & ns & 0.16 & $*$ \\
\hline D-dimer & 0.087 & ns & 0.092 & ns & 0.24 & $* *$ & 0.041 & ns & 0.000 & ns & 0.005 & ns & 0.037 & ns \\
\hline Platelet count & 0.17 & $*$ & 0.095 & ns & 0.29 & $* * * *$ & 0.17 & $*$ & 0.11 & ns & -0.009 & ns & 0.23 & $* *$ \\
\hline Neutrophil count & 0.10 & ns & 0.13 & ns & 0.19 & $*$ & 0.047 & ns & 0.041 & ns & -0.008 & ns & 0.096 & ns \\
\hline Calprotectin & 0.26 & $* * *$ & 0.29 & $* * * *$ & 0.28 & $* * *$ & 0.11 & ns & 0.090 & ns & 0.25 & $* * *$ & 0.23 & $* *$ \\
\hline NETs (MPO/DNA) & 0.18 & $*$ & 0.16 & $*$ & 0.25 & $* * *$ & 0.20 & $* *$ & 0.13 & ns & 0.033 & ns & 0.23 & $* *$ \\
\hline
\end{tabular}

ns, not significant; NETs, neutrophil extracellular traps; MPO, myeloperoxidase; ${ }^{*} \mathrm{p}<0.05$, ${ }^{* *} \mathrm{p}<0.01,{ }^{* * *} \mathrm{p}<0.001$, and ${ }^{* * * *} \mathrm{p}<0.0001$

₹ 36 patients had serum samples from multiple time points; for those patients only the first available serum sample was used for determining correlations. 